Article

\title{
Climate Warming-Induced Changes in Plant Phenology in the Most Important Agricultural Region of Romania
}

\author{
Georgeta Bandoc ${ }^{1,2, *}$, Adrian Piticar ${ }^{3}$, Cristian Patriche ${ }^{4}\left(\mathbb{D}\right.$, Bogdan Roșca ${ }^{4, *}$ and Elena Dragomir ${ }^{1,5}$ \\ 1 Faculty of Geography, University of Bucharest, 1 Nicolae Bălcescu Str., 010041 Bucharest, Romania; \\ hellen.dragomir@googlemail.com \\ 2 Academy of Romanian Scientists, 54 Splaiul Independentei Str., 050094 Bucharest, Romania \\ 3 Faculty of Aeronautical Management, Henry Coanda Air Force Academy, 160 Mihai Viteazul Str., \\ 500183 Brasov, Romania; adrian.piticar@ubbcluj.ro \\ 4 Geographic Research Center, Iaşi Division, Romanian Academy, 8 Carol I Str., 700505 Iaşi, Romania; \\ pvcristi@yahoo.com \\ 5 Center for Coastal Research and Environmental Protection, 1 Nicolae Bălcescu Str., 010041 Bucharest, Romania \\ * Correspondence: bandoc@geo.unibuc.ro (G.B.); roscao@gmail.com (B.R.)
}

check for updates

Citation: Bandoc, G.; Piticar, A.; Patriche, C.; Roșca, B.; Dragomir, E. Climate Warming-Induced Changes in Plant Phenology in the Most Important Agricultural Region of Romania. Sustainability 2022, 14, 2776 https://doi.org/10.3390/su14052776

Academic Editor: Sean Clark

Received: 22 December 2021

Accepted: 24 February 2022

Published: 26 February 2022

Publisher's Note: MDPI stays neutral with regard to jurisdictional claims in published maps and institutional affiliations.

Copyright: (C) 2022 by the authors. Licensee MDPI, Basel, Switzerland. This article is an open access article distributed under the terms and conditions of the Creative Commons Attribution (CC BY) license (https:// creativecommons.org/licenses/by/ $4.0 /$ )

\begin{abstract}
Changes in plant phenology are a direct indicator of climate change and can produce important consequences for agricultural and ecological systems. This study analyzes changes in plant phenology in the 1961-2010 period (for both the entire interval and in three successive multidecades: 1961-1990, 1971-2000 and 1981-2010) in southern and southeastern Romania, the country's most important agricultural region. The analysis is based on mean monthly air temperature values collected from 24 regional weather stations, which were used for extracting the length (number of days) of phenophases (growing season onset, budding-leafing, flowering, fruiting, maturing, dissemination of seeds, start of leaf loss, end of leaf loss) and of the overall climatic growing season (CGS, which includes all phenophases), by means of the histophenogram method. Using a number of reliable statistical tools (Mann-Kendall test, Sen's slope estimator and the regression method) for exploring annual trends and net (total) changes in the length of the phenological periods, as well as for detecting the climate-growing season statistical relationships, our results revealed complex phenology changes and a strong response in phenological dynamics to climate warming. Essentially, a lengthening of all phenophases (maximal in the maturing period, in terms of statistical significance and magnitude of trends-on average 0.48 days/yr/24 days net change in the 1961-2010 period, or even 0.94 days/yr / 28 days net change in the 1971-2000 sub-period) was noticed, except for the fruiting and dissemination phenophases, which were dominated by negative trends in the number of days, but partially statistically significant (at a confidence level threshold of at least $90 \%$ ). The CGS exhibited overall increasing trends, with an average of 0.21 days/yr/11 days net change in the 19612010 interval, and even of 0.90 days/yr/27 days net change in the 1981-2010 sub-period. Moreover, based on the slope values obtained upon application of a linear regression to mean temperature and CGS, we discovered that a $1{ }^{\circ} \mathrm{C}$ increase in climate warming accounted for a remarkable lengthening of the CGS, on average of 14 days between 1961 and 2010, and of 16 days between 1981 and 2010. Our results can help improve the adaptation of agroecological systems to future climate change.
\end{abstract}

Keywords: phenology; phenophases; climatic growing season; change; climate warming

\section{Introduction \\ 1.1. Plant Phenology under Climate Warming}

Climate change, and in particular the considerable change in air temperature, has triggered important shifts in plant phenological cycles (or phenophases, which are specific biological events that comprise part of the annual life cycle of plants) in large areas worldwide [1]. According to some remote sensing-based studies, plant phenology changed 
considerably after 1981, i.e., on 54\% of the Earth's terrestrial area [2]. While the phenological response to climate change represents a global phenomenon that varies largely across regions [3-5], it is unanimously acknowledged that the most apparent changes in phenological cycles occurred in the past decades in the boreal and temperate regions of the Northern Hemisphere $[2,6,7]$. However, the degree of phenological shifts is not only dependent on the rate of climate change or of other non-climatic factors, but also on the plant species' response to external perturbations [3].

Plant phenology is highly sensitive to climate variability and climate change, and is an important bioindicator of climatic changes [8-13]. Clear evidence of long-term changes in plant phenology among temperate and boreal regions in the Northern Hemisphere was mainly linked to temperature changes, which represents the main control factor of this type of ecosystem dynamics at middle and high latitudes $[1,5,13,14]$. While there are also other environmental variables that can influence plant phenology, such as photoperiod, precipitation, atmospheric $\mathrm{CO}_{2}$, and nitrogen deposits [5,14-18], the influence of these factors is generally inferior to that of temperature.

In many parts of the world, evidence of growing season length (GSL) changes was brought forward upon analysis of climate [19-25], satellite [26-32] and phenological [8,10,33-37] data. These studies, as well as others, generally signaled the lengthening of the growing season (particularly in temperate and high-latitude regions of the Northern Hemisphere) especially due to the earlier onset of spring, since temperature in this season has significantly increased in the past decades $[5,22,24,36,38,39]$. Moreover, a delayed autumn season explains, to a certain extent, the lengthening of the growing season in many regions of the planet.

As a general rule, GSL increased globally by approximately 3-4 days/decade after 1970 [40], and it was found that this ecological parameter had overall increased, in the past decades, by about 10-20 days in most parts of the world [16]. In Europe, it was discovered that, between 1971 and 2000, GSL had increased by 2.5 days/decade during spring events, and by 1.3 days/decade during autumn phases [41], which highlights the greater importance of spring phenological changes compared to autumn. It was suggested that this indicator had recorded a total increase across the European continent of almost 11 days after 1951, according to phenological records, and reached as high as approximately 19 days after 1982, according to satellite data [14,16,42,43].

Changes in phenological events may pose numerous risks to natural vegetation and crops, such as an increase in consequential insect pest damage, and frost damage due to earlier occurrences of phenological events [44]. Temporal phenological mismatching can also lead to the disruption of key plant-animal interactions that may alter ecosystem functions [45]. Moreover, phenological changes can generate significant effects in terms of terrestrial-climate feedbacks and ecosystem functionality, primarily by modifying the photosynthetic activity of plants, carbon sequestration and ecosystem productivity $[39,40,46]$. In the final instance, an in-depth understanding of phenological changes may be crucial to an improved comprehension of climate-carbon cycle feedbacks $[47,48]$ and, implicitly, to a better understanding of future climate change.

Assessing phenological changes for areas where only climate data are available can provide essential information with respect to ecosystem response to climatic changes [3]. Moreover, these types of studies are useful for detecting early signs of ecosystem transitions amid climate change in a specific region [44]. Given this context, the analysis of phenological changes via climatic approaches (based on climatological records), more specifically by analyzing the climatic growing season statistically, bears the advantage of enabling a fast extraction of phenological information, when no phenological data records are available for a given territory. However, this approach is considered representative if the study area's phenology is mainly controlled by temperature, as is the case for a temperate region [14,49], where most of the European continent-and implicitly Romania-is located. Therefore, the analysis of the climatic growing season-the period during which plant development can theoretically occur (which is assessed based on certain thermal thresholds, between which vegetation can grow) and which does not perfectly coincide with the period of actual 
growth [50] — can be a highly useful tool in the analysis of phenological dynamics across extensive areas and over long periods of time.

In Romania, few studies have analyzed changes in plant phenophases and GSL. Their findings revealed that changes in phenological events were strongly related to warmer climatic conditions $[25,51-56]$. However, increasing air temperature trends were directly or indirectly documented in Romania in numerous climate studies, carried out both nationally [57-63] and regionally/locally [64-71], which indirectly highlights clues regarding the country's potential phenological changes. These clues are all the more relevant for the agricultural region in southern and south-eastern Romania (Romanian Plain and Dobrogea Plateau), which saw, over recent decades, some of the highest positive trends in mean temperatures [68]. Considering these trends were most apparent in spring and summer (net/total warming as high as almost $3{ }^{\circ} \mathrm{C}$ in the period 1961-2009), i.e., two seasons that cover most of the growing season (the start and peak phases of plant phenological activity), we expect significant changes in phenophases and in the growing season, based on the premise that plant phenology in Romania (and generally in the temperate region) is primarily controlled by air temperature $[5,25]$.

\subsection{Objective, Novelty and Structure of the Study}

The present study aims to analyze phenological trends (phenophases and the overall climatic growing season) spatially and temporally in southern and south-eastern Romania, in the past half-century. Unlike the only other previous study conducted in this area, as well as countrywide, which analyzed phenophases and the overall vegetation season dynamics based on climatological records (in terms of post-1990 changes versus the 19611990 period) [25], our paper aims to deliver new (from three standpoints) results on the dynamics of this ecological issue in Romania.

Firstly, this study analyzes, for the first time, the annual trends of the length of all phenological cycles (phenophases) and of the CGS, for the 1961-2010 period in addition to the three multi-decade periods: 1961-1990, 1971-2000 and 1981-2010. In this case, the three-decade analyses (the minimum required for statistical climate investigations) were considered useful for a deeper understanding of phenological changes in southern and southeastern Romania. Secondly, this is the first study to analyze the net phenological changes of phenophases/the growing season that occurred in the four periods. Thirdly, our approach is the first to analyze the statistical relationship between regional climate warming and vegetation season dynamics, using representative methodological tools.

Therefore, this paper essentially attempts to generate new data on plant phenology trends and on the impact of climate warming on vegetation season dynamics in this major region of the country. In line with this goal, the paper is structured into several sections and sub-sections, which are aimed at briefly assessing the geographical (eco-climatic) conditions of the study area, presenting the data used, explaining the geostatistical methods applied, examining the results obtained, and discussing the relevance, limitations and implications of the findings.

\section{Data and Methods}

\subsection{Study Area}

The study area consists of southern and south-eastern Romania (which comprises three major landforms-Romanian Plain, Dobrogea Plateau and the Danube Delta) (Figure 1) and totals almost $64,000 \mathrm{~km}^{2}$, or $27 \%$ of the country's area. Climatically (thermally), this is the region where the country's highest mean annual temperatures are recorded, mainly due to the low topography (the maximum altitude is $467 \mathrm{~m}$, in the plateau region) and Mediterranean influences in the west (which account for higher temperatures in the warm season, and moderate temperatures in the cold season), and continental (which generally results in high summer temperatures, but also in low winter temperatures) and Black Sea (moderating role in the coastal area, by determining higher winter temperatures and lower 
summer temperatures, compared to the inland area of the Dobrogea region) influences in the north-east and east [68,72].

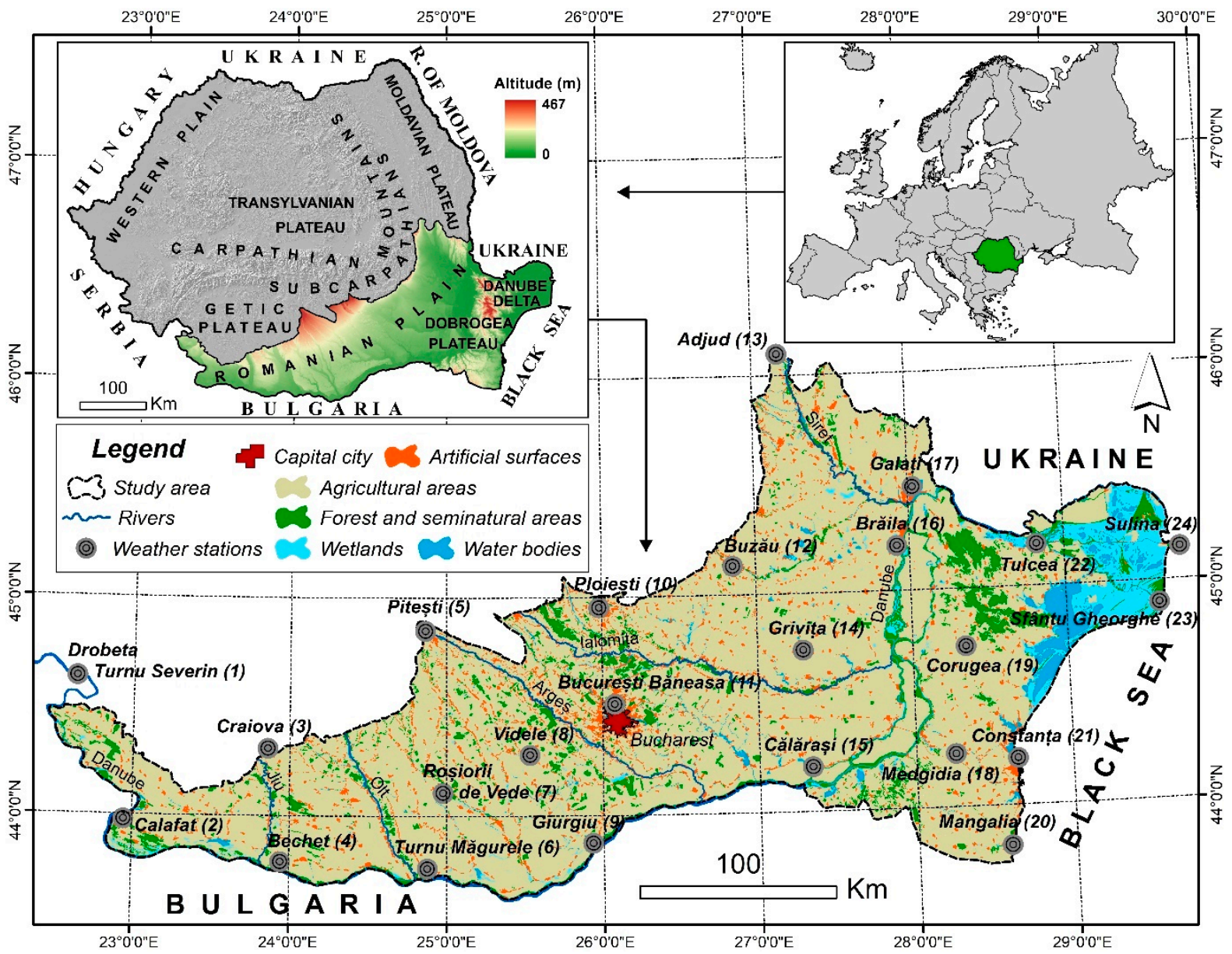

Figure 1. Study area in Romania, its geographical characteristics and the locations of the analyzed weather stations in the region. Note: the land use/cover classes were mapped based on the CORINE Land Cover database (2018 edition) [73].

Mean multiannual temperatures reach $9.7^{\circ} \mathrm{C}$ in the north-east, and $12.2^{\circ} \mathrm{C}$ in the south-west, with notable seasonal differences-between -1.5 and $2.2{ }^{\circ} \mathrm{C} / 20$ and $22.6{ }^{\circ} \mathrm{C}$ in the winter/summer seasons, and between 9.5 and $12.4{ }^{\circ} \mathrm{C} / 10$ and $13.2^{\circ} \mathrm{C}$ in transitional spring/autumn seasons [68]. Phenologically, the mean multiannual length of the climatic growing season (estimated indirectly based on mean temperature values, via application of the histophenogram method) ranges from 235 days (Adjud weather station, north-east) to 275 days (Constanta station, south-east) [25] (Figure 1; Table 1). Moreover, the mean length of the phenological cycles that are part of the overall CGS generally ranges between 25 and 35 days, except for phenophase 5 (maturing, the length of which generally ranges from 80 to 90 days) and, in part, phenophase 4 (fruiting, generally from 30 to 40 days) [25] (Table 1). 
Table 1. Geographic coordinates and mean multiannual length (in number of days) of phenophases and climatic growing season at the analyzed weather stations, in the 1961-2010 period.

\begin{tabular}{|c|c|c|c|c|c|c|c|c|c|c|c|c|c|}
\hline \multirow[b]{2}{*}{ No. ${ }^{a}$} & \multirow[b]{2}{*}{ Weather Stations } & \multirow[b]{2}{*}{ Latitude (N) } & \multirow[b]{2}{*}{$\begin{array}{l}\text { Longitude } \\
\text { (E) }\end{array}$} & \multirow[b]{2}{*}{ Alt. (m) } & \multicolumn{9}{|c|}{ Mean Length of Phenophases (P) and Climatic Growing Season (CGS) } \\
\hline & & & & & $\mathbf{P} 1^{\mathrm{c}}$ & $\mathbf{P 2}$ & $\mathbf{P 3}$ & $\mathbf{P 4}$ & P5 & P6 & P7 & P8 & $\begin{array}{c}\text { CGS } \\
\text { (P2-P8) }\end{array}$ \\
\hline 1 & Drobeta T. S. & $44^{\circ} 37^{\prime} 35^{\prime \prime}$ & $22^{\circ} 37^{\prime} 34^{\prime \prime}$ & 78.2 & 4 March & 30 & 28 & 37 & 91 & 27 & 26 & 27 & 266 \\
\hline 2 & Calafat & $43^{\circ} 59^{\prime} 06^{\prime \prime}$ & $22^{\circ} 56^{\prime} 46^{\prime \prime}$ & 62.2 & 8 March & 27 & 27 & 34 & 90 & 28 & 26 & 24 & 256 \\
\hline 3 & Craiova & $44^{\circ} 18^{\prime} 37^{\prime \prime}$ & $23^{\circ} 52^{\prime} 01^{\prime \prime}$ & 193.2 & 10 March & 29 & 28 & 39 & 80 & 30 & 26 & 24 & 256 \\
\hline 4 & Bechet & $43^{\circ} 47^{\prime} 23^{\prime \prime}$ & $23^{\circ} 56^{\prime} 39^{\prime \prime}$ & 37.2 & 11 March & 25 & 27 & 33 & 88 & 28 & 25 & 26 & 252 \\
\hline 5 & Pitești & $44^{\circ} 50^{\prime} 56^{\prime \prime}$ & $24^{\circ} 51^{\prime} 58^{\prime \prime}$ & 317.2 & 19 March & 24 & 30 & 50 & 45 & 37 & 28 & 27 & 241 \\
\hline 6 & Turnu Măgurele & $43^{\circ} 45^{\prime} 37^{\prime \prime}$ & $24^{\circ} 52^{\prime} 42^{\prime \prime}$ & 31.6 & 6 March & 26 & 29 & 33 & 96 & 29 & 24 & 26 & 263 \\
\hline 7 & Roșiorii de Vede & $44^{\circ} 06^{\prime} 26^{\prime \prime}$ & $24^{\circ} 58^{\prime} 43^{\prime \prime}$ & 103.4 & 15 March & 24 & 27 & 34 & 83 & 29 & 24 & 26 & 247 \\
\hline 8 & Videle & $44^{\circ} 16^{\prime} 58^{\prime \prime}$ & $25^{\circ} 32^{\prime} 13^{\prime \prime}$ & 107 & 15 March & 29 & 22 & 33 & 84 & 29 & 25 & 25 & 247 \\
\hline 9 & Giurgiu & $43^{\circ} 52^{\prime} 31^{\prime \prime}$ & $25^{\circ} 55^{\prime} 58^{\prime \prime}$ & 24.8 & 11 March & 25 & 26 & 34 & 90 & 25 & 26 & 26 & 252 \\
\hline 10 & Ploiesti & $44^{\circ} 57^{\prime} 21^{\prime \prime}$ & $25^{\circ} 59^{\prime} 15^{\prime \prime}$ & 178.2 & 17 March & 22 & 26 & 40 & 68 & 31 & 27 & 26 & 240 \\
\hline 11 & București Băneasa & $44^{\circ} 30^{\prime} 38^{\prime \prime}$ & $26^{\circ} 04^{\prime} 41^{\prime \prime}$ & 91.2 & 15 March & 25 & 28 & 33 & 78 & 29 & 26 & 27 & 246 \\
\hline 12 & Buzău & $45^{\circ} 07^{\prime} 58^{\prime \prime}$ & $26^{\circ} 51^{\prime} 06^{\prime \prime}$ & 98.3 & 14 March & 26 & 26 & 32 & 86 & 28 & 26 & 25 & 249 \\
\hline 13 & Adjud & $46^{\circ} 06^{\prime} 17^{\prime \prime}$ & $27^{\circ} 10^{\prime} 13^{\prime \prime}$ & 101.9 & 22 March & 22 & 27 & 45 & 55 & 33 & 26 & 27 & 235 \\
\hline 14 & Grivița & $44^{\circ} 44^{\prime} 27^{\prime \prime}$ & $27^{\circ} 17^{\prime} 41^{\prime \prime}$ & 51.1 & 17 March & 25 & 26 & 39 & 90 & 25 & 23 & 26 & 254 \\
\hline 15 & Călărași & $44^{\circ} 12^{\prime} 21^{\prime \prime}$ & $27^{\circ} 20^{\prime} 18^{\prime \prime}$ & 19.9 & 17 March & 28 & 29 & 33 & 93 & 29 & 28 & 27 & 267 \\
\hline 16 & Brăilá & $45^{\circ} 12^{\prime} 24^{\prime \prime}$ & $27^{\circ} 55^{\prime} 11^{\prime \prime}$ & 15.7 & 16 March & 25 & 26 & 34 & 81 & 28 & 26 & 27 & 247 \\
\hline 17 & Galați & $45^{\circ} 28^{\prime} 23^{\prime \prime}$ & $28^{\circ} 01^{\prime} 56^{\prime \prime}$ & 70.3 & 18 March & 24 & 26 & 34 & 80 & 29 & 26 & 26 & 245 \\
\hline 18 & Medgidia & $44^{\circ} 14^{\prime} 36^{\prime \prime}$ & $28^{\circ} 15^{\prime} 05^{\prime \prime}$ & 70.7 & 15 March & 28 & 27 & 35 & 76 & 32 & 27 & 28 & 253 \\
\hline 19 & Corugea & $44^{\circ} 44^{\prime} 04^{\prime \prime}$ & $28^{\circ} 20^{\prime} 31^{\prime \prime}$ & 220.4 & $24 \mathrm{March}$ & 24 & 26 & 38 & 70 & 30 & 26 & 28 & 242 \\
\hline 20 & Mangalia & $43^{\circ} 48^{\prime} 58^{\prime \prime}$ & $28^{\circ} 35^{\prime} 15^{\prime \prime}$ & 7.2 & 16 March & 33 & 27 & 34 & 78 & 32 & 31 & 31 & 266 \\
\hline 21 & Constanța & $44^{\circ} 12^{\prime} 50^{\prime \prime}$ & $28^{\circ} 38^{\prime} 44^{\prime \prime}$ & 14 & 16 March & 39 & 32 & 27 & 88 & 30 & 30 & 29 & 275 \\
\hline 22 & Tulcea' & $45^{\circ} 11^{\prime} 26^{\prime \prime}$ & $28^{\circ} 49^{\prime} 27^{\prime \prime}$ & 5.6 & 16 March & 26 & 26 & 35 & 78 & 32 & 27 & 29 & 253 \\
\hline 23 & Sfântu Gheorghe & $44^{\circ} 53^{\prime} 52^{\prime \prime}$ & $29^{\circ} 35^{\prime} 56^{\prime \prime}$ & 2 & 21 March & 25 & 27 & 32 & 79 & 31 & 31 & 31 & 256 \\
\hline 24 & Sulina & $45^{\circ} 08^{\prime} 54^{\prime \prime}$ & $29^{\circ} 45^{\prime} 32^{\prime \prime}$ & 13.4 & 20 March & 26 & 24 & 35 & 83 & 31 & 28 & 31 & 258 \\
\hline 25 & Mean ${ }^{b}$ & - & - & 79.8 & 15 March & 26.5 & 27.0 & 35.5 & 80.4 & 29.7 & 26.6 & 27.0 & 252.8 \\
\hline
\end{tabular}

Note: ${ }^{\text {a }}$-stations are ordered from west to east, based on increasing longitude coordinate values; ${ }^{\mathrm{b}}$ - the average of all weather station values, representative for the entire study area; ${ }^{\mathrm{c}}$ - starting date of growing season, based on which the first phenophase was delimited (according to the information presented in the "Methods" section); P1—growing season onset, P2 - budding-leafing, P3—flowering, P4 - fruiting, P5—maturing, P6-dissemination of seeds, P7-start of leaf loss, P8 - end of leaf loss, CGS - total number of days of all phenophases; phenophases were delimited based on the following temperature thresholds/intervals: $5^{\circ} \mathrm{C}(\mathrm{P} 1), 5-10{ }^{\circ} \mathrm{C}(\mathrm{P} 2), 10-15^{\circ} \mathrm{C}(\mathrm{P} 3)$, $15-20{ }^{\circ} \mathrm{C}(\mathrm{P} 4), 20-25^{\circ} \mathrm{C}(\mathrm{P} 5), 20-15{ }^{\circ} \mathrm{C}(\mathrm{P} 6), 15-10{ }^{\circ} \mathrm{C}(\mathrm{P} 7)$ and $10-5{ }^{\circ} \mathrm{C}(\mathrm{P} 8)$.

The analysis of phenological changes can be highly useful for the study area, especially given the region's agroecological importance. It holds roughly $40 \%$ of Romania's total agricultural area, or almost half of the country's total arable area (maize and wheat are the most important agricultural crops) [68]. Thus, most of the analyzed area is covered by agricultural land (Figure 1), which accounts for $78 \%$ of the study area and mainly consists of arable land (about $70 \%$ of the total study area). Analyzing phenological changes can be crucially important in the context of such environmental changes which can generate significant implications for the productivity of agricultural crops, such as maize (Zea mays L.), the phenology of which is strongly dependent on air temperature conditions [74].

\subsection{Methodology}

\subsubsection{Climate Data}

For the analysis of phenological dynamics and of its relationship with climate warming, we employed mean monthly air temperature values $\left({ }^{\circ} \mathrm{C}\right)$ collected from 24 weather stations distributed uniformly across the study area (Figure 1 ). The analyzed period covered a 50-year period (1961-2010), and the data were provided by the National Meteorology Administration [75] for stations 2, 4, 5, 8, 9, 10, 13, 14, 16, 18, 19, 20 and 23 (Figure 1, Table 1), while the daily temperature values for the remaining 11 stations were extracted from the ECA\&D data platform [76] - the daily data were subsequently processed as mean monthly values (Figure 1, Table 1). The data interval was only updated to 2010 in order to cover exactly 5 decades, but especially considering the limited availability of open-source and up-to-date climate data in Romania-for instance, the ROCADA dataset represents one of the most important nationally, and provides free climate data, which is; however, only updated to 2013 [77].

The data from both sources homogenously covered the 1961-2010 period. With the exception of a few stations for which data were unavailable for certain years (in which case the values were estimated by means of linear regression, based on continuous data collected 
from the nearest stations - the method was deemed viable considering the constant nature of temperatures and especially the high values of $r$ correlation coefficients, (close to 1 in most cases), the analyzed stations provided continuous data series for the entire 1961-2010 period.

\subsubsection{Methods}

Extraction of Annual Data for Phenophase and Climatic Growing Season Lengths

As we used climatic data, which in this instance features the advantage of covering the entire analyzed area over a long period of time (compared to phenological records and satellite data, which are absent, unavailable or limited to the last 2-3 decades), phenology phases were delimited based on the temperature criterion. Our approach is therefore based on analyzing the CGS, which can be defined as the period in which vegetation growth can occur theoretically (i.e., this is not a period of actual growth for a given plant species, the delimitation of which usually requires phenological records), depending on certain key temperature thresholds [16]. Moreover, in addition to data accessibility, we deemed this ecological approach useful and representative from a climatic perspective, considering that, as previously mentioned, temperature is widely known as the main control factor of plant phenology, at least in the temperate region, where the study area is located $[14,16,25,49,78-80]$.

Based on these considerations and seeing as there is no universally established methodology for estimating the CGS [16], we employed the histophenogram method for identifying the CGS period and its constituting phenophases. As a result of the more general data that were available to us (mean monthly values), our approach to CGS as a general ecological parameter is not identical to traditional studies. A significant share of the studies, which focused on determining the growing season length and on analyzing theoretical plant phenology dynamics, are based on identifying a number of consecutive days (at the beginning and the end of the CGS) with mean daily temperature values that were superior/inferior to a given air temperature value [23,81-84].

In concrete terms, the histophenogram method consists of a system of rectangular axes that integrates the months of the year on the $x$-axis (length of monthly segments corresponds to the number of days of each month), and mean monthly temperatures on the $y$-axis (Figure 2). Drawing a line through the points that correspond to the middle of the months on the $x$-axis and to mean monthly temperatures on the $y$-axis results in obtaining each year's thermal curve. Afterwards, by setting thermal thresholds on the $y$-axis, 5 degrees Celsius apart (from 5 to $25^{\circ} \mathrm{C}$, as this interval is typical for the growing season in Romania, as well as in other countries in the temperate region), and by drawing perpendicular lines on the $x$-axis (axis of time) from the points where the thresholds cross the thermal curve, we obtained the start and end dates of phenological cycles and of the CGS (and therefore their lengths in days), based on the days where the perpendicular lines crossed the time axis (Figure 2). The thermal curve tracing in the histophenogram, starting with $5{ }^{\circ} \mathrm{C}$, is linked to the fact that this minimal thermal threshold triggers the biological and phenological activity of vegetation [50,79,81,85-88].

Therefore, the lengths of phenophase 1 (P1, growing season onset, delimited based on the $5{ }^{\circ} \mathrm{C}$ threshold that marks the beginning of plant biological activity), phenophase 2 (P2, budding-leafing, $\left.5-10^{\circ} \mathrm{C}\right)$, phenophase $3\left(\mathrm{P} 3\right.$, flowering, $\left.10-15^{\circ} \mathrm{C}\right)$, phenophase $4(\mathrm{P} 4$, fruiting, $\left.15-20^{\circ} \mathrm{C}\right)$, phenophase $5\left(\mathrm{P} 5\right.$, maturing, 20-25 $\left.{ }^{\circ} \mathrm{C}\right)$, phenophase $6(\mathrm{P} 6$, dissemination of seeds, $\left.20-15^{\circ} \mathrm{C}\right)$, phenophase 7 (P7, start of leaf loss, $\left.15-10^{\circ} \mathrm{C}\right)$, phenophase $8(\mathrm{P} 8$, end of leaf loss, $10-5^{\circ} \mathrm{C}$ ) and of the overall growing season (P2-P8) were obtained based on this methodology (Figure 2). It must be mentioned that P1 is not an actual phenophase, but rather a theoretical point (day) in which plant phenological activity starts (P1 was however quantified in a number of days, in relation to the start of the year), which is why we believe it is more accurate to define CGS as the period of plant biological activity that spans from P2 to P8. All the aforementioned information, as well as other details on histophenogram methodology, were described in a series of specialized Romanian papers $[25,78,79,89]$. 


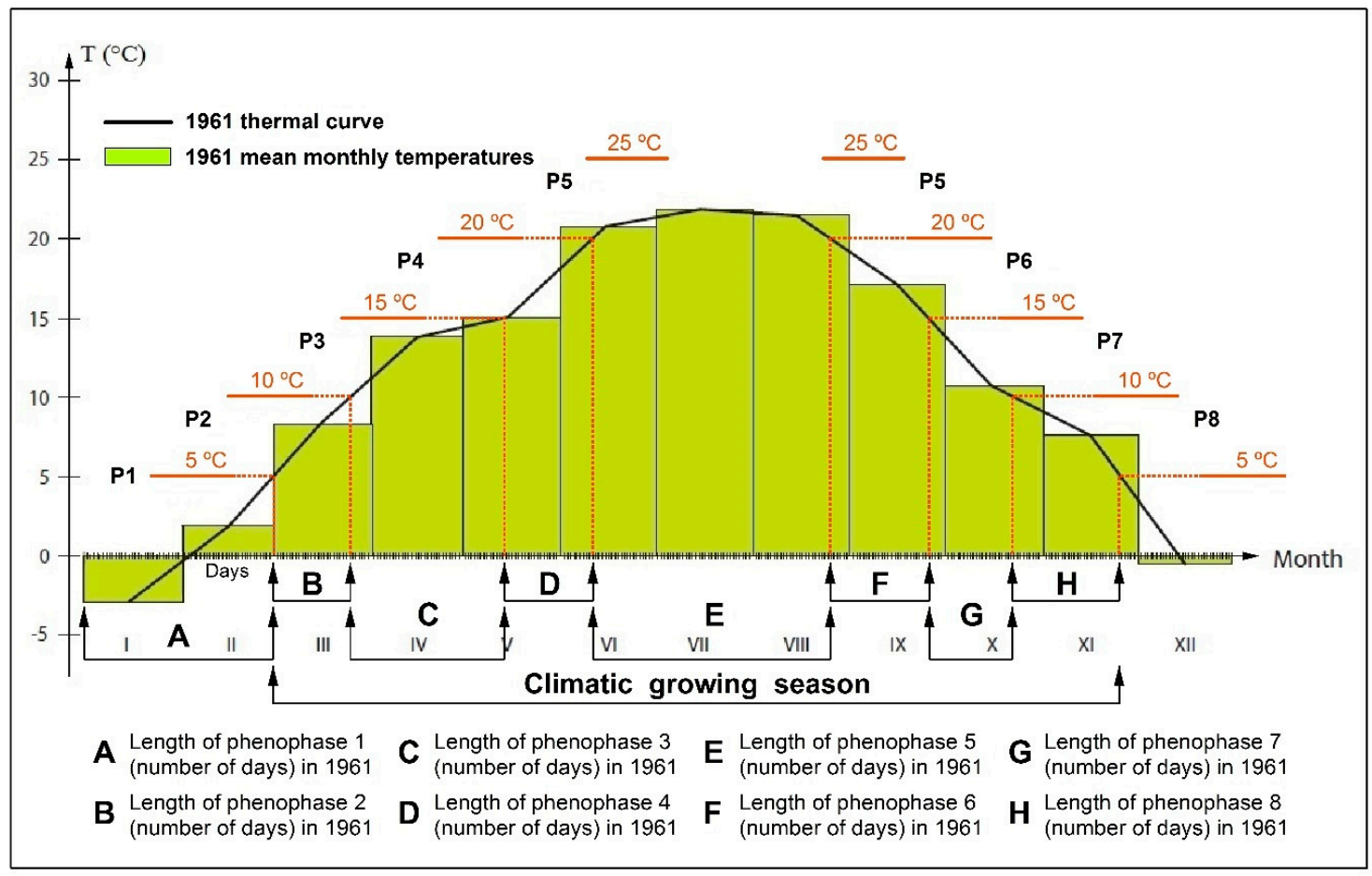

Figure 2. Example of extraction of phenophase and climatic growing season length (number of days) using the histophenogram method, at the Bucharest Băneasa weather station, 1961. Note: phenophase 1-growing season onset, phenophase 2-budding-leafing, phenophase 3-flowering, phenophase 4-fruiting, phenophase 5-maturing, phenophase 6-dissemination, phenophase 7-start of leaf loss, phenophase 8-end of leaf loss, phenophases 2-8-climatic growing season.

The extraction of phenological data was performed using the MATLAB software [90]. Considering the software's technical nature and the need to extract a large volume of data, we created a histophenogram for each year and weather station, which resulted in a total of 1200 histophenograms (50 years times 24 weather stations) that were analyzed. Our study is therefore based on the processing of approximately 10,000 final data, considering the number of days extracted for the 8 phenophases and the CGS from the 1200 histograms.

Detection of Annual Phenological Trends

In order to detect and analyze annual trends (or changes/yr) of the extracted lengths of phenophases and CGS, we used the statistical tools (in their basic forms) Mann-Kendall test [91,92] and Sen's slope estimator [93], via the MAKESENS Excel application [94]. The Mann-Kendall test assesses the statistical significance of a trend, while Sen's slope provides information on the magnitude of a downward or upward trend in a given time series [94,95]. Detailed information on the two methods, which feature certain advantages such as not needing a normal data distribution, can be found in Salmi et al. (2002) [94], as well as in many other published papers, especially in the climate change field.

In this paper, all positive or negative trends were analyzed in relation to $\alpha$ significance thresholds of the Mann-Kendall test-0.1, 0.05, 0.01 and 0.001 (which correspond to 90, 95, 99 and 99.9\% confidence levels), which have been used (integrally) in many studies on air temperature changes [53,96-99], the climatic parameter on which the extraction of our phenological data is based. Stationary trends, which represent cases with a slope value of 0.000 [100], were also considered. Although all trend investigations were performed for the entire 1961-2010 period, we also deemed it useful to conduct other more detailed analyses on successive multi-decades 1961-1990, 1971-2000 and 1981-2010. We chose to carry out these more detailed statistical investigations in order to identify the most recent phenological changes (1981-2010) on the basis of available data, all while complying with the principle 
of analyzing a climate data set of at least 30 years, to ensure that it is considered statistically relevant. Moreover, in order to synthesize the results obtained, all trends were presented on multiple maps, created using the spatial analysis software ArcGIS 10.1 [101].

The Mann-Kendall test and Sen's slope estimator are two methods that can also be used for phenological approaches such as ours, considering they have been largely employed to assess changes in plant phenological cycles, based on climate, satellite, and phenological data [30,38,102-109]. We believe the use of such tools is all the more important in the present study as, to the best of our knowledge, this is the first time the two methods have been applied for investigating phenological changes over an extensive geographical area in Romania. As previously mentioned, only one past study [25] analyzed phenological changes based on climatic data, but without using different time intervals and methods (only detection of phenological changes post-1990 versus 1961-1990, i.e., without an analysis in terms of the annual rate of changes over the entire period or in the three consecutive multi-decade periods).

\section{Detection of Net Phenological Changes}

In addition to detecting annual rates, this paper analyses net changes in phenophases and the CGS, or the total changes that occurred in the 1961-2010 period (annual rates multiplied by 50) and in the three consecutive multi-decade periods (annual rates multiplied by 30). In other words, the net phenological changes were obtained starting from the rates initially detected as changes/yr, which were subsequently multiplied by the total number of years in the five and three decades, respectively. These changes were assessed by means of spatial interpolations of net change data, computed for all weather stations in the region. The spatial interpolations were performed in R environment [110], by using the ordinary kriging method with spherical and circular models, the variograms of which generated the best results (considering the smallest residual errors). Finally, the resulting raster data were mapped using the ArcGIS 10.1 software.

\section{Analysis of the Relationship between Climate Warming and CGS Dynamics}

Moreover, we deemed it interesting and useful to analyze the statistical relationship between the increase in regional temperatures, demonstrated in the study area by previous studies [68], and the possible lengthening of the CGS at the analyzed weather stations. This possible impact of climate warming on phenology was assessed via a linear regression analysis of mean annual temperatures and the annual CGS length, the most important indicator of phenological dynamics. The linear regression was only applied to intervals 1961-2010 and 1981-2010, considering this, according to a previous study in the analyzed area, climate warming was only statistically founded on a large scale in these periods [68].

The regression analysis was performed in Excel/XLSTAT trial version software [111]. Firstly, regression parameters (intercept, slope, $\mathrm{R}^{2}$, adjusted $\mathrm{R}^{2}, \mathrm{r}, p$ values) were computed using specific formulas in Excel. Secondly, regression residuals were computed, and 5 normality tests (Shapiro-Wilk, Anderson-Darling, Lilliefors, Jarque-Bera, Chi-square) were applied in order to determine whether they follow normal distributions. Some outliers were identified and removed where most of the tests indicated a lack of fit. For the 19612010 period, one observation was removed from each weather station in Pitesti (1962), Videle (1988) and Corugea (1973). Moreover, for the 1981-2010 period, one observation was eliminated, but only for the Videle (1988) weather station.

\section{Results}

\subsection{Annual Phenological Trends}

Our results, obtained by applying the Mann-Kendall and Sen's slope methods, highlighted significant phenological changes in the study area. The first phenophase exhibited decreasing trends for the number of days between the onset of phenological activity and the start of the year, which shows an early start of plant biological activity, and therefore a lengthening of the growing season in the first part of the year (Figure 3). While these 
decreasing trends are exclusive to all multi-decade periods (except for 1971-2000, which also had certain stationary trends), they are statistically significant especially in the 19612010 interval (Figures 3 and 4). However, it is interesting to note that, in terms of trend magnitude, the highest change rates are found in the last three decades, both for individual cases $(-0.58$ days $/ y r)$ and in terms of the mean spatial value of all rates recorded at the 24 weather stations ( -0.40 days $/ y r$, a rate that is almost twice as high as that of the overall 50-year period) (Figure 3, Table 2).

Phenophase 2 (budding-leafing) stands out with exclusively positive trends (which translates into the lengthening of this plant phenological cycle) in the 1961-2010 period, which were however statistically significant in only $13 \%$ of cases (Figures 3 and 4 ). In the successive multi-decade periods, overall phenological changes in the study area are unclear in terms of trends, with the partial exception of the 1961-1990 interval, which contains largely dominant increasing trends that reach a maximum value that is actually three times greater (0.40 days/yr) than that of 1961-2010 (0.14 days/yr) (Figure 3). On average, the 0.15 days/yr value, the highest of all multi-decade intervals, indicates the largest footprint of the first three decades in general changes of phenophase 2, identified in the overall five-decade period (Table 2).

Phenophase 3 (flowering) contains the most apparent cases of null changes out of all analyzed phenophases (Figures 3 and 4). It was found that stationary trends were present in roughly $50-60 \%$ of cases in all periods, except for the 1981-2010 interval, when positive trends, present in almost $90 \%$ of weather stations, became increasingly apparent (Figure 4). On average, the positive annual trend of the post-1981 period measures three times higher than those of the other analyzed intervals (Table 2).

Negative trends were identified in the length (number of days) of the fourth phenological cycle (fruiting) in three of the four analyzed periods (Figure 3). While the overall five-decade period showed significant decreases, the most apparent negative annual trends were found, in this instance, in the 1971-2000 period, in terms of mean spatial value $(-0.43$ days/yr) and statistical significance (67\%) (Figure 4, Table 2). Considering these two aspects, it can be deduced that this multi-decade interval is the most important one for the general dynamics of phenophase 4 in the 1961-2010 interval, even though decreasing trends reached a peak individual value after 1981 ( -1.10 days/yr, in the north-east) (Figure 3).

It is interesting to note that phenophase 5 (maturing) exhibited the most aggressive lengthening trends in the overall analyzed phenological context (except for the 1961-1990 period, marked by opposite and statistically insignificant trends), in terms of high rates and statistical significance (Figures 3 and 4). While the overall 1961-2010 period stands out with the most apparent trend statistical significance (92\%, similar to the 1971-2000 interval, but with more cases of $\alpha$ at the maximum confidence threshold, 0.001), the 19712000 multi-decade contained the highest recorded rates (Figures 3 and 4). Although one individual case reached 1.80 days/yr (the highest value identified in this study, noticed in the north-east, at the Adjud weather station), on average, the rates bear a value of 0.94 days/yr (which is also the study's highest mean spatial value) (Table 2).

While the sixth phenophase (dissemination) also stands out, similar to phenophase 4, with the reduction of its duration, in this instance the negative trends are universal (in all four periods) and, for the most part, statistically significant (especially between 1961 and 2010, when they reached $83 \%$ of the total) (Figures 3 and 4). However, maximum negative rates were found in this instance as well between 1971 and 2000, both for individual cases ( -0.75 days/yr) and the mean spatial value ( -0.30 days/yr) (Figure 3, Table 2). Therefore, this three-decade period appears to also maintain the largest footprint in the general changes of phenophase 6 identified in the overall five-decade period. 


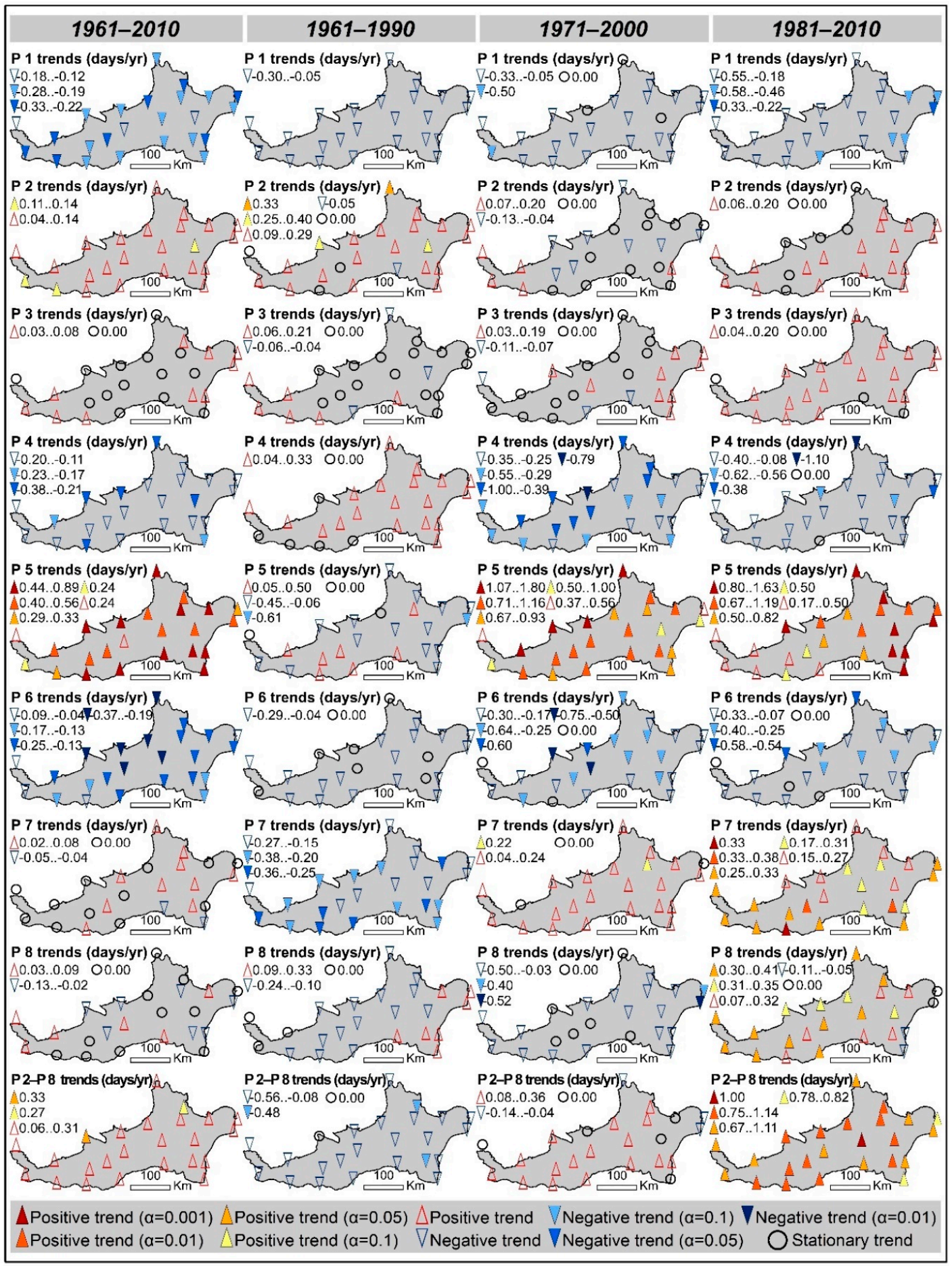

Figure 3. Trends (direction, magnitude and statistical significance) in the phenophases and climatic growing season in the 1961-2010, 1961-1990, 1971-2000 and 1981-2010 periods. Note: P1phenophase 1 (growing season onset), P2-phenophase 2 (budding-leafing), P3-phenophase 3 (flowering), P4-phenophase 4 (fruiting), P5-phenophase 5 (maturing), P6-phenophase 6 (dissemination), P7-phenophase 7 (start of leaf loss), P8-phenophase 8 (end of leaf loss), P2-P8—climatic growing season; the blue/yellow-red shades indicate a decrease/increase in phenological activity; the first phenophase (P1) provides an exception to this rule, as its negative trends indicate less days from the beginning of the year to the onset of biological activity and, therefore, a longer growing season in the first part of the year (in this case, blue shades must therefore be interpreted as an increase in biological activity in the first part of the year). 

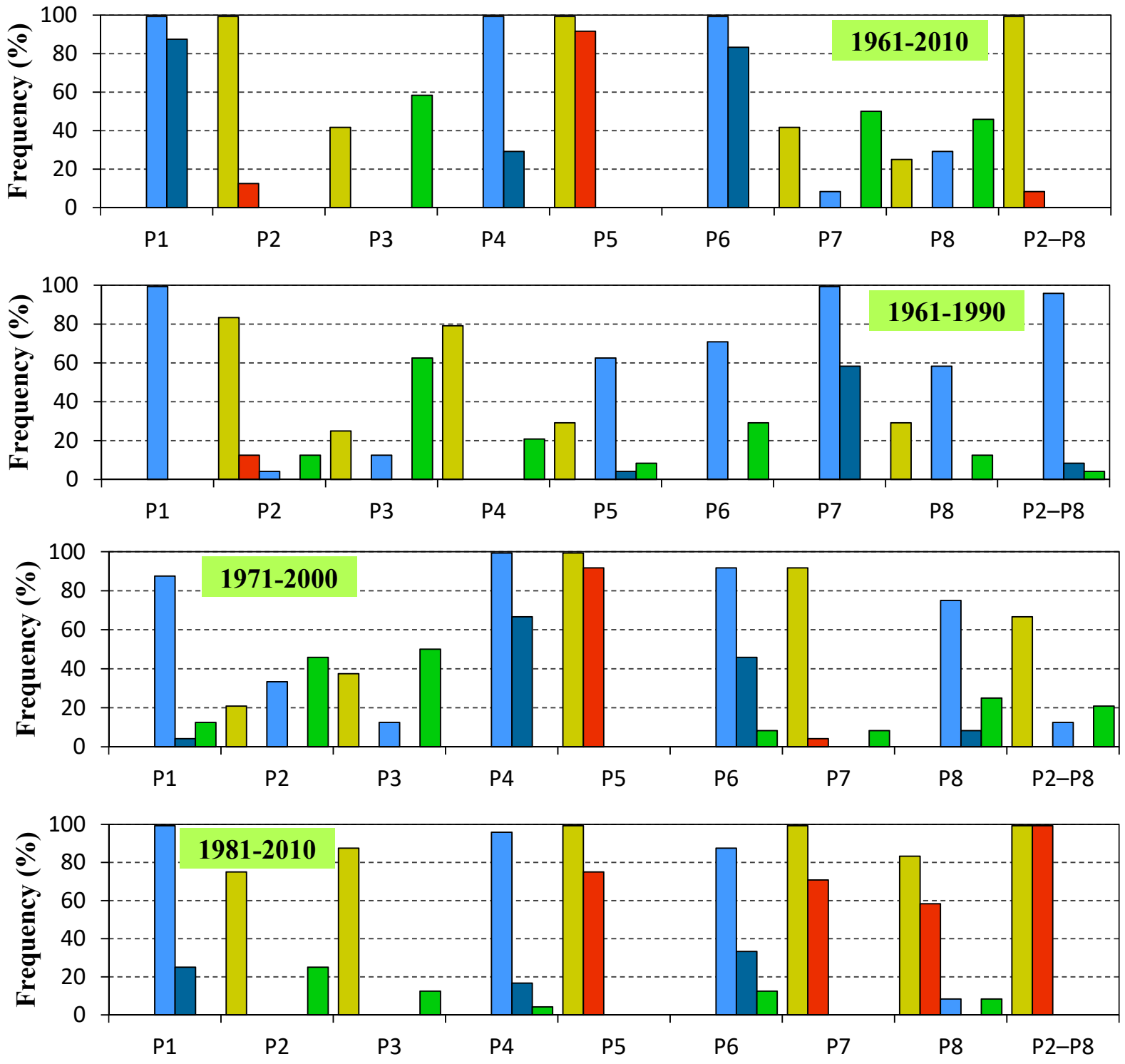

$\square$ Total positive trends $\square$ Total sig. positive trends $\square$ Total negative trends $\square$ Total sig. negative trends $\square$ Stationary trends

Figure 4. Trend frequency (in the 1961-2010, 1961-1990, 1971-2000 and 1981-2010 periods) of phenophases and of the climatic growing season, according to direction (positive/negative/stationary) and statistical significance (significant/insignificant). Note: P1phenophase 1 (growing season onset), P2-phenophase 2 (budding-leafing), P3-phenophase 3 (flowering), P4-phenophase 4 (fruiting), P5—phenophase 5 (maturing), P6-phenophase 6 (dissemination), P7-phenophase 7 (start of leaf loss), P8-phenophase 8 (end of leaf loss), P2-P8—climatic growing season.

Phenophases 7 (start of leaf loss) and 8 (end of leaf loss) show largely similar dynamics, e.g., stationary/opposite trends in the 1961-2010 period (Figure 3). The main difference can be noticed in the 1971-2000 interval, which contains positive trends for phenophase 7, and negative/stationary trends for phenophase 8 (Figure 3). However, the 1981-2010 period must be noted, as this is when increasing trends for the number of days became apparent, both in terms of statistical significance (in over $50 \%$ of cases for both phenological cycles) and mean spatial value (identical rates of 0.26 days/yr) (Figure 4, Table 2).

The entire CGS (P2-P8) is characterized, in the 1961-2010 period, exclusively by lengthening trends of phenological activity, albeit with limited statistical significance (below 10\%) (Figures 3 and 4). This changes in the past three decades, where much clearer positive trends can be noticed, primarily in terms of statistical confidence- $100 \%$, which 
renders the analyzed phenological instance the only one with fully statistically significant trends (Figures 3 and 4). The 1981-2010 CGS interval is also remarkable due to bearing the highest mean spatial rate of all analyzed post-1981 phenological cases-0.90 days/yr (Table 2), which proves the clear intensification of phenological activity in the past decades in southern and south-eastern Romania.

Table 2. Mean spatial values of annual trends (days/year) in phenophase and climatic growing season (CGS) length, in the 1961-2010, 1961-1990, 1971-2000 and 1981-2010 periods.

\begin{tabular}{ccccc}
\hline Time/Phenophases \& CGS & 1961-2010 & $\mathbf{1 9 6 1 - 1 9 9 0}$ & $\mathbf{1 9 7 1 - 2 0 0 0}$ & $\mathbf{1 9 8 1 - 2 0 1 0}$ \\
\hline Phenophase 1 & -0.22 & -0.16 & -0.15 & -0.40 \\
Phenophase 2 & 0.10 & 0.15 & 0.00 & 0.08 \\
Phenophase 3 & 0.02 & 0.03 & 0.03 & 0.10 \\
Phenophase 4 & -0.18 & 0.14 & -0.43 & -0.29 \\
Phenophase 5 & 0.48 & -0.12 & 0.94 & -0.80 \\
Phenophase 6 & -0.18 & -0.10 & -0.30 & 0.26 \\
Phenophase 7 & 0.01 & -0.25 & 0.11 & 0.26 \\
Phenophase 8 & 0.00 & -0.05 & -0.15 & 0.90
\end{tabular}

Note: the values were obtained by averaging the annual trends recorded at the 24 weather stations.

\subsection{Net Phenological Changes}

The analysis of total phenological changes in the analyzed 50/30-year periods highlighted earlier growing season onsets (phenophase 1), in certain local cases by up to roughly 17 days between 1961 and 2010, or by roughly 18 days in the past three decades (Figure 5). On average, the most apparent net negative changes, of approximately 11 and roughly 12 days, were also noticed in the two periods (Table 3).

The budding-leafing phenophase recorded the highest increases in the 1961-2010 and 1961-1990 intervals, locally (about 7 days, and 12 days, respectively) and on average (roughly 5 days for both instances) (Figure 5, Table 3). While positive changes were also found in the flowering phenophase, these were mainly low-intensity changes, except for a part of the post-1981 period (average increase of approximately 3 days) (Table 3).

In the fruiting phenophase, we identified mean net reductions of approximately 9 days between 1961 and 2010, which rose to roughly 13 days between 1971 and 2000 (Table 3). However, locally, total negative changes climb as high as approximately 19 days, and 30 days in the two mentioned intervals (Figure 5). As expected, according to the analysis of annual rates, the maturing phenophase exhibited the most significant net lengtheningon average by approximately 24 days in the five decades and by over 28 days between 1971 and 2000 (the maximum value in the successive multi-decade context) (Table 3). The maximum local expansions of this ecological cycle are impressive as well, as they reach roughly 45 days / 54 days in the two intervals (Figure 5).

It was discovered that, in the dissemination cycle, while the maximum and average local reductions of the phenological duration were similar to those of the fruiting phenophase in the 1961-2010 period, they were lower multidecadally (Figure 5, Table 3). In the final phenological cycles, start of leaf loss and end of leaf loss, the total phenological activity increase is apparent especially in the last three decades, when both instances recorded mean expansions of almost 8 days and, locally, as high as approximately 12 days (Figure 5, Table 3). In the final analyzed case, the overall CGS contained a mean net lengthening of approximately 11 days (or up to roughly 17 days considering the peak local value) between 1961 and 2010, and as high as 27 days (or roughly 34 days as a maximum local value) after 1981 (Figure 5, Table 3). 


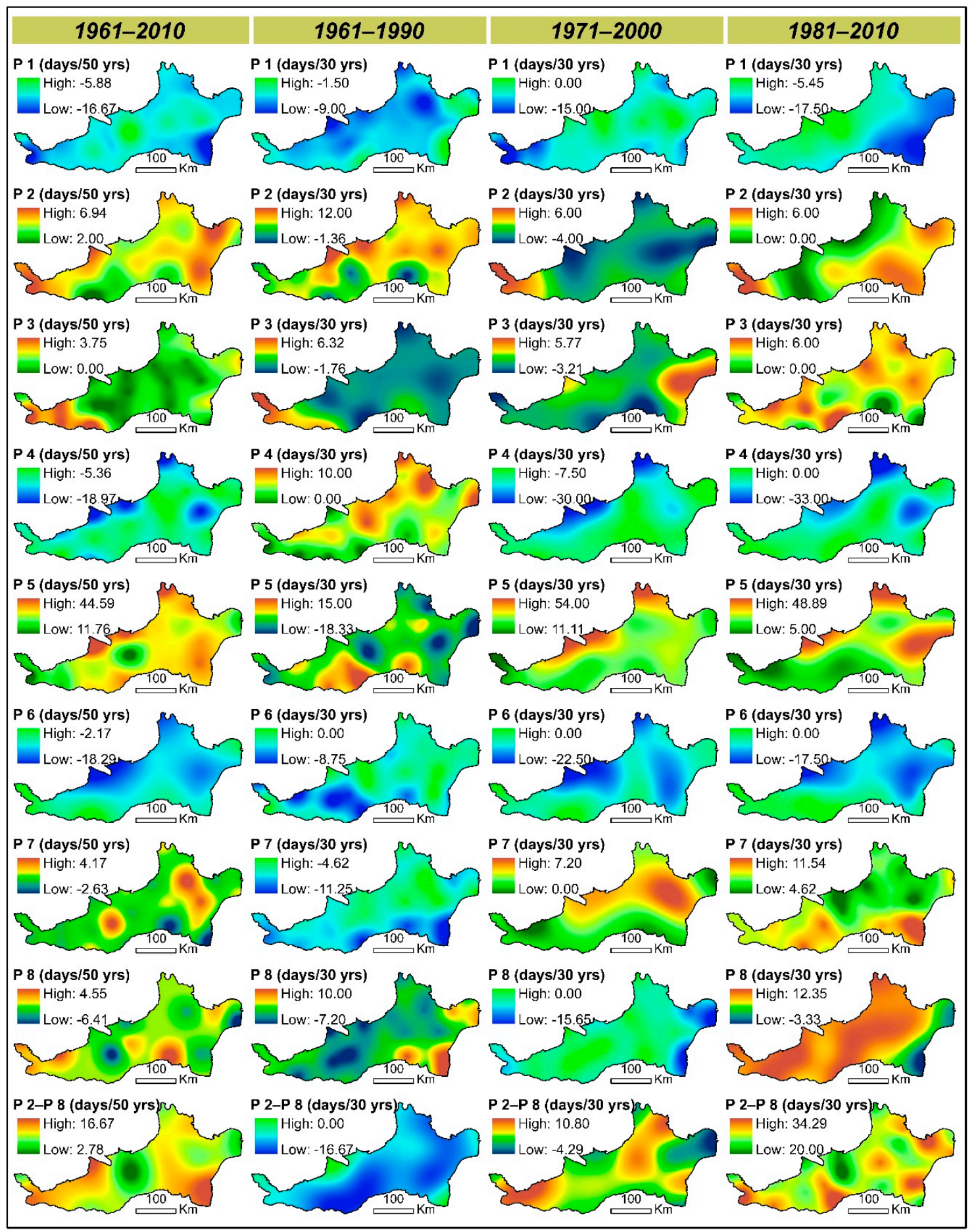

Figure 5. Net changes of the phenophases and climatic growing season in the 1961-2010, 1961-1990, 1971-2000 and 1981-2010 periods. Note: P1—phenophase 1 (growing season onset), P2-phenophase 2 (budding-leafing), P3 - phenophase 3 (flowering), P4-phenophase 4 (fruiting), P5—phenophase 5 (maturing), P6-phenophase 6 (dissemination), P7-phenophase 7 (start of leaf loss), P8-phenophase 8 (end of leaf loss), P2-P8—climatic growing season; the blue-green/green-brown/blue-brown shades indicate net negative/positive/mixed changes in phenological activity; the first phenophase (P1) provides an exception to this rule, as its net negative changes indicate fewer days from the beginning of the year to the onset of biological activity and, therefore, a longer growing season in the first part of the year (in this case, blue-green shades must be interpreted as an increase in biological activity in the first part of the year). 
Table 3. Mean spatial values of net changes (days/50/30/30/30 years) in phenophase and climatic growing season (CGS) length, in the 1961-2010, 1961-1990, 1971-2000 and 1981-2010 periods.

\begin{tabular}{ccccc}
\hline Time/Phenophases \& CGS & $\mathbf{1 9 6 1 - 2 0 1 0}$ & $\mathbf{1 9 6 1 - 1 9 9 0}$ & $\mathbf{1 9 7 1 - 2 0 0 0}$ & $\mathbf{1 9 8 1 - 2 0 1 0}$ \\
\hline Phenophase 1 & -11.22 & -4.94 & -4.59 & -11.92 \\
Phenophase 2 & 4.96 & 4.56 & 0.01 & 2.49 \\
Phenophase 3 & 0.94 & 0.83 & 0.81 & 2.98 \\
Phenophase 4 & -8.88 & 4.08 & -13.02 & -8.73 \\
Phenophase 5 & 23.97 & -3.59 & 28.25 & 23.86 \\
Phenophase 6 & -8.81 & -2.99 & -9.06 & -6.10 \\
Phenophase 7 & 0.72 & -7.56 & 3.41 & 7.66 \\
Phenophase 8 & -0.09 & -1.42 & -4.64 & 7.71 \\
CGS (phenophases 2-8) & 10.56 & -10.73 & 3.22 & 26.89
\end{tabular}

Note: the values were obtained by averaging the net changes recorded at the 24 weather stations.

\subsection{Impact of Climate Warming on the Lengthening of the Climatic Growing Season}

As the CGS was delimited based on temperature values, statistical relationships are likely to be discovered between mean annual temperature variability and CGS length dynamics. In fact, these clear relationships are expectable especially for the 1961-2010 and 1981-2010 periods, considering that a previous study conducted in the region [68] showed notable annual climate warming (in terms of statistical significance) especially in these periods (more specifically in highly similar intervals that were analyzed in said study, namely 1961-2009 and 1981-2009). Considering this, in addition to the results the study generated on partially/totally statistically significant increasing trends of the CGS in the two periods, we deemed it necessary and representative to analyze the climate-phenology relationship only in the 1961-2010 and 1981-2010 intervals.

The results of the linear regression therefore confirmed a significant consistency between the two variables in the two intervals. In the first analyzed period, 1961-2010, it was noticed that determination coefficients $\left(\mathrm{R}^{2}\right.$, essential statistical parameter that indicates the extent to which the variation of the dependent variable, in this case CGS, is determined by the variation of the independent variable, mean temperatures) showed high statistical significance in all 24 analyzed cases (weather stations) (Table 4). It was found that temperature dynamics accounted for CGS variation to various degrees that range from 33\% (Pitesti and Ploiești weather stations, north of the study area) to 54\% (Calafat, southwest) (Figure 1, Table 4). On average, the extent to which CGS variability is accounted for by temperature dynamics is $46 \%$ (Table 4 ).

Moreover, the analysis of slope values is particularly important, considering they express the sensitivity of CGS dynamics/lengthening to a temperature variation of one unit. Therefore, the values of this statistical parameter (which reflects a direct relationship between the two variables, i.e., temperature increase-CGS expansion) indicates CGS lengthening values that range from 10 days (Pitești and Ploiesti) to 18 days (Tulcea and Mangalia, in the northeast, and southeast, respectively), for every $1{ }^{\circ} \mathrm{C}$ rise in temperature (Figure 1, Table 4). On average, a 14-day CGS increase was linked to a $1{ }^{\circ} \mathrm{C}$ rise in temperature (Table 4).

The second analyzed period, 1981-2010, highlighted an even more apparent response of CGS to climate warming. In this instance, $\mathrm{R}^{2}$ coefficient values (also highly statistically significant at all weather stations) indicated an even higher dependence of CGS on temperature variability, ranging from 39\% (Sulina, east) to 68\% (Calafat) (Figure 1, Table 5). Our results indicated a mean CGS-temperature dependence of 53\%. 
Table 4. Regression parameters resulting from the analysis between mean annual temperatures $\left({ }^{\circ} \mathrm{C}\right)$ and annual length of climatic growing season (number of days) for the 24 weather stations (1961-2010 period).

\begin{tabular}{|c|c|c|c|c|c|c|c|c|}
\hline No. $^{a}$ & Weather Stations & Sample Size & Intercept & Slope & $\mathrm{R}^{2}$ Adjusted & $\mathbf{r}$ & $p$-Value & Significance $^{b}$ \\
\hline 1 & $\begin{array}{c}\text { Drobeta Turnu } \\
\text { Severin }\end{array}$ & 50 & 109.296 & 12.835 & 0.365 & 0.615 & $<0.001$ & High \\
\hline 2 & Calafat & 50 & 57.098 & 17.281 & 0.543 & 0.743 & $<0.001$ & High \\
\hline 3 & Craiova & 50 & 94.485 & 14.325 & 0.429 & 0.664 & $<0.001$ & High \\
\hline 4 & Bechet & 50 & 65.230 & 16.639 & 0.509 & 0.720 & $<0.001$ & High \\
\hline 5 & Pitești & 49 & 146.765 & 9.787 & 0.325 & 0.582 & $<0.001$ & High \\
\hline 6 & Turnu Măgurele & 50 & 108.844 & 12.734 & 0.400 & 0.642 & $<0.001$ & High \\
\hline 7 & Roșiorii de Vede & 50 & 100.490 & 13.572 & 0.467 & 0.691 & $<0.001$ & High \\
\hline 8 & Videle & 49 & 118.987 & 11.935 & 0.450 & 0.679 & $<0.001$ & High \\
\hline 9 & Giurgiu & 50 & 83.555 & 14.977 & 0.473 & 0.696 & $<0.001$ & High \\
\hline 10 & Ploiești & 50 & 139.989 & 10.131 & 0.334 & 0.589 & $<0.001$ & High \\
\hline 11 & București Băneasa & 50 & 98.901 & 13.944 & 0.457 & 0.684 & $<0.001$ & High \\
\hline 12 & Buzău & 50 & 106.230 & 12.998 & 0.496 & 0.712 & $<0.001$ & High \\
\hline 13 & Adjud & 50 & 132.121 & 10.952 & 0.476 & 0.698 & $<0.001$ & High \\
\hline 14 & Grivița & 50 & 109.541 & 12.805 & 0.453 & 0.681 & $<0.001$ & High \\
\hline 15 & Călărásisi & 50 & 78.811 & 15.621 & 0.480 & 0.701 & $<0.001$ & High \\
\hline 16 & Brăila' & 50 & 102.787 & 13.425 & 0.521 & 0.728 & $<0.001$ & High \\
\hline 17 & Galați & 50 & 112.368 & 12.524 & 0.514 & 0.724 & $<0.001$ & High \\
\hline 18 & Medgídia & 50 & 79.320 & 15.992 & 0.510 & 0.721 & $<0.001$ & High \\
\hline 19 & Corugea & 49 & 110.150 & 13.005 & 0.481 & 0.701 & $<0.001$ & High \\
\hline 20 & Mangalia & 50 & 62.124 & 17.756 & 0.471 & 0.694 & $<0.001$ & High \\
\hline 21 & Constanța & 50 & 73.479 & 16.462 & 0.471 & 0.694 & $<0.001$ & High \\
\hline 22 & Tulcea & 50 & 49.594 & 18.452 & 0.475 & 0.697 & $<0.001$ & High \\
\hline 23 & Sfântu Gheorghe & 50 & 68.300 & 16.920 & 0.488 & 0.706 & $<0.001$ & High \\
\hline 24 & Sulina & 50 & 97.803 & 14.001 & 0.370 & 0.619 & $<0.001$ & High \\
\hline
\end{tabular}

Note: ${ }^{a}$ —stations are ordered from west to east, based on increasing longitude coordinate values; ${ }^{\mathrm{b}}$ —statistical significance is considered high for $p$ values $<0.05$.

Table 5. Regression parameters resulting from the analysis of mean annual temperatures $\left({ }^{\circ} \mathrm{C}\right)$ and of the annual length of the climatic growing season (number of days) for the 24 weather stations (1981-2010 period).

\begin{tabular}{|c|c|c|c|c|c|c|c|c|}
\hline No. ${ }^{a}$ & Weather Stations & Sample Size & Intercept & Slope & $\mathbf{R}^{2}$ Adjusted & $\mathbf{r}$ & $p$-Value & Significance $^{b}$ \\
\hline 1 & $\begin{array}{c}\text { Drobeta Turnu } \\
\text { Severin }\end{array}$ & 30 & 64.855 & 16.118 & 0.495 & 0.716 & $<0.001$ & High \\
\hline 2 & Calafat & 30 & 9.545 & 21.009 & 0.676 & 0.829 & $<0.001$ & High \\
\hline 3 & Craiova & 30 & 57.544 & 17.325 & 0.495 & 0.716 & $<0.001$ & High \\
\hline 4 & Bechet & 30 & 26.368 & 19.849 & 0.636 & 0.805 & $<0.001$ & High \\
\hline 5 & Pitești & 30 & 121.647 & 12.018 & 0.462 & 0.693 & $<0.001$ & High \\
\hline 6 & Turnu Măgurele & 30 & 83.166 & 14.616 & 0.458 & 0.690 & $<0.001$ & High \\
\hline 7 & Roșiorii de Vede & 30 & 86.816 & 14.601 & 0.515 & 0.729 & $<0.001$ & High \\
\hline 8 & Videle & 29 & 105.225 & 13.008 & 0.515 & 0.729 & $<0.001$ & High \\
\hline 9 & Giurgiu & 30 & 56.813 & 16.886 & 0.600 & 0.783 & $<0.001$ & High \\
\hline 10 & Ploiești & 30 & 111.350 & 12.611 & 0.506 & 0.723 & $<0.001$ & High \\
\hline 11 & București Băneasa & 30 & 103.544 & 13.363 & 0.443 & 0.680 & $<0.001$ & High \\
\hline 12 & Buzău & 30 & 84.122 & 14.785 & 0.558 & 0.757 & $<0.001$ & High \\
\hline 13 & Adjud & 30 & 111.291 & 12.918 & 0.585 & 0.774 & $<0.001$ & High \\
\hline 14 & Grivița & 30 & 90.605 & 14.369 & 0.511 & 0.726 & $<0.001$ & High \\
\hline 15 & Călărași & 30 & 72.621 & 15.934 & 0.498 & 0.718 & $<0.001$ & High \\
\hline 16 & Brăila & 30 & 82.694 & 15.103 & 0.614 & 0.792 & $<0.001$ & High \\
\hline 17 & Galați & 30 & 103.612 & 13.183 & 0.509 & 0.725 & $<0.001$ & High \\
\hline 18 & Medgídia & 30 & 75.262 & 16.190 & 0.561 & 0.759 & $<0.001$ & High \\
\hline 19 & Corugea & 30 & 94.248 & 14.390 & 0.542 & 0.747 & $<0.001$ & High \\
\hline 20 & Mangalia & 30 & 27.019 & 20.491 & 0.604 & 0.786 & $<0.001$ & High \\
\hline 21 & Constanța & 30 & 53.142 & 17.984 & 0.545 & 0.749 & $<0.001$ & High \\
\hline 22 & Tulcea & 30 & 36.840 & 19.402 & 0.479 & 0.705 & $<0.001$ & High \\
\hline 23 & Sfântu Gheorghe & 30 & 46.497 & 18.670 & 0.553 & 0.754 & $<0.001$ & High \\
\hline 24 & Sulina & 30 & 77.146 & 15.600 & 0.389 & 0.641 & $<0.001$ & High \\
\hline
\end{tabular}

Note: ${ }^{a}$ — stations are ordered from west to east, based on increasing longitude coordinate values; ${ }^{b}$ — statistical significance is considered high for $p$ values $<0.05$. 
We additionally observed considerable CGS expansions for a $1{ }^{\circ} \mathrm{C}$ rise in temperature, with minimum values of 12 days (Pitești) and maximum values of 21 days (Calafat) (Table 5). Therefore, in the past three decades, slope values are significantly higher compared to the overall 1961-2010 period, which translates into a stronger impact of the most recent climate warming onto phenological changes. This finding is also confirmed by the higher mean slope value at all 24 weather stations, which indicates a 16-day CGS lengthening for a $1^{\circ} \mathrm{C}$ rise in temperature.

\section{Discussions}

Our analysis confirms the occurrence of phenological changes in this major region of Romania, as an important consequence of the climate warming affecting both the study area [68] and the entire national territory [59] over the past decades. Our results, which proved in most cases statistically-founded changes in phenological events and the CGS, can contribute to a better understanding of this ecological issue's dynamics in the past half-century, especially since such approaches remain almost non-existent in Romania. This explains why the results cannot be compared to previous similar regional or national studies-identical or even remotely similar methodologies have not yet been applied. As previously mentioned in the paper, while a partial exception consists of the research conducted in the region (based on the histophenogram method) by Bandoc et al. (2018) [25], our findings cannot be compared to this previous study's results, as they only cover post-1990 phenological changes and are not based on well-established tools such as the Mann-Kendall test and Sen's slope estimator. However, an overall comparison can be drawn, i.e., the resulting pattern of phenological dynamics in the most recent period (post-1981) is consistent with that noticed after 1990-growing season lengthening as a consequence of both earlier spring onsets and delayed autumn events.

Internationally, the state of affairs is radically different, as there are numerous phenological studies based on climatic data that are analyzed, among others, using the two aforementioned well-established statistical methods. For instance, a representative study, which covered the entire Northern Hemisphere, showed that the climatic (or thermal) growing season lengthened in this extensive planetary region at a rate of 2.86 days per decade in the 1980-2011 period [112]. Considering the CGS lengthening rate identified in our study in the similar 1981-2010 period (0.90 days/yr or 9 days/decade), it can be noticed that the phenological activity lengthening occurred in the study area three times faster compared to the overall Northern Hemisphere. However, this difference is lower when considering Eurasia, where post-1980 CGS changes of 4.00 days/decade were observed [112]. Even in this instance, the change rate of this ecological parameter remains significantly higher (more than double) in our results. At the same time, although there have been other large-scale studies conducted in the Northern Hemisphere that signal important phenological changes in past decades [14,113], comparing them to our study is less relevant considering the different methods they employed, mainly based on remote sensing data analysis.

Since the CGS represented the main phenological indicator that various studies analyzed based on the $5^{\circ} \mathrm{C}$ temperature criterion (studies on CGS phenological sub-periods, such as the phenophases we delimited, are far rarer internationally), other comparisons can be drawn nationally. For instance, in China, mean lengthening values for the thermal growing season of 2 days/decade, and of 2.7 days/decade were found in the relatively similar 1961-2015 and 1981-2015 periods [23]. When comparing our study to this Asian country which has been intensely studied in terms of phenological changes, we can see much higher post-1981 rates, but almost identical post-1961 values ( 2.1 days/decade). In another example, the post-1961 CGS expansion rate in this area of Romania is relatively similar to that recorded in Poland (2.5 days/decade) in the 1951-2010 period [24]. Other important examples in the Northern Hemisphere are Canada and the United States, where notable CGS lengthening trends were signaled-1.15 days/decade between 1980 and 2011 
(mean trend of the two countries) [112], which is far lower than the post-1981 trends resulting from this study.

In order to further contextualize our results, other comparisons, from other points of view (that extend beyond the actual trend), can also be suggestive. For instance, the total CGS expansion can provide an interesting basis of comparison. Considering the Northern Hemisphere, where it can indirectly be concluded that the total lengthening of the growing season reached approximately 9 days in the 1980-2011 period (considering the rate of 0.286 days /yr over the 31-year period) [112], our findings show that the 27-day net CGS increase between 1981 and 2010 is also three times higher in southern and southeastern Romania, compared to this global spatial reference unit. Even the net lengthening of the thermal growing season in Eurasia, of approximately 12 days, remains significantly lower in the past three decades, compared with this major Romanian region. Moreover, it is interesting to note that a $1{ }^{\circ} \mathrm{C}$ rise in temperature appears to determine changes in the growing season that are far more aggressive in the study area (14 days between 1961-2010) compared to the European instance (5 days between 1969 and 1998) [114]. However, this comparison must be regarded with caution considering the different period and data (phenological records for particular plant species) used in the analysis conducted on the European continent.

Another important mention must be made with regard to the identified phenophase dynamics pattern. It is generally known that, in the past half-century, the increase of the growing season was due to the earlier onset of spring phenology and, to a lesser extent, to the later onset of autumnal phenological events, both globally and in Europe [5,36,39]. This asymmetry found between spring and autumn phenological cycles can be identified in the present study as well (as it can be observed that the changes in the first phenophases generally consist of higher rates, when compared with the last phenophases), especially when considering the overall five-decade period. However, our analysis showed that this pattern changed after 1981 in the region (and, most likely, countrywide), when the first phenological cycles became relatively balanced in relation to the autumn cycles, in terms of lengthening trend magnitude. These results on the CGS change from asymmetrical to symmetrical expansion, in the past three decades, are consistent with previous findings obtained in the Northern Hemisphere [112]. This regional state of affairs is due to higher temperatures recorded in autumn [68], similarly to the hemisphere-related context in which an unprecedented autumn warming also occurred in the previous decades [112].

However, we recommend that this paper's findings be interpreted cautiously, considering certain potential shortcomings related to the exclusive use of mean temperature data in the analysis of phenological changes. For example, the minimum and maximum temperature values can bear an influence on the phenological cycles of plants $[115,116]$. Furthermore, it is known that the photoperiod is also an important factor for plant growth, especially in spring phenological events $[117,118]$, while precipitation can influence phenological activity in certain cases [15].

Therefore, while the impact of these additional climate variables was not captured in our study (since the histophenogram was generated and analyzed based on monthly average thermal values), we wish to stress the fact that there may be other possible limitations of this research. For example, changes in some plants' (crops) phenology are not attributed only to climate change and are determined by technical anthropic (agricultural) practices such as the timing of sowing and harvesting, sowing density, and breeding strategies [119]. At the same time, a limitation in and of itself is the investigated period 1961-2010, which does not capture the very recent phenological changes of the last decade (2011-2020), due to certain reasons previously stated in this paper. In the context of all said limiting conditions, we recommend that future studies focus on the analysis of phenological changes through more complex data (climate and phenological records) that is as up-to-date as possible, depending on their free availability in the near future.

There are various implications of the phenological changes highlighted in this Romanian region. While CGS lengthening is associated with certain positive effects for vegetation 
such as the increase in primary productivity, certain negative effects can; however, result against the background of an extended growing season. For instance, the earlier CGS onset can produce negative effects due to the higher probability of early spring frosting affecting agricultural crops, which cover extensive areas in the analyzed region (Figure 1). Therefore, the decreasing trends of phenophase 1 can determine the earlier development of plants and even cause sterility due to exposure to extreme temperatures. Another example consists of changes in the budding-leafing and flowering phenophases, which can disrupt the relationship between plants and pollinators by offsetting the flowering period in relation to that of pollinating insect development [120].

\section{Conclusions}

The present paper attempts to deliver new insights on phenology dynamics in a major region of Romania, the south and southeast, over the past half-century. Using mean air temperature values collected from 24 weather stations, uniformly distributed throughout the region, and several methodological tools for extracting and analyzing phenophase and CGS length trends, our results highlighted the complex phenological changes that occurred in the 1961-2010 period in this agroecologically important region. The study's results reflect, for the first time, various changes in plant phenology, which were approached via certain previously unexplored statistical aspects, such as annual change rates, net changes and the relationship between climate warming and growing season lengthening. These changes essentially highlighted the lengthening of plant phenology (both for phenophases, except for the fruiting and dissemination periods, and for the overall growing season) in the five-decade period and especially in the 1981-2010 interval. At the same time, our study proved a high sensitivity of growing season changes to the regional increase in mean annual temperatures.

Therefore, we discovered the shift in plant phenology to be consistent with the climatic warming pattern that affected the analyzed territory. A relevant example to support this consists of the increase in phenological activity noticed especially in the past three decades, which stand out with the most intense climate warming, both nationally and globally. Given this context, we wish to stress the need to conduct similar regional or national studies, which could prove highly useful considering the possible phenological changes recorded countrywide, in the context of the previous studies that confirmed an overall climatic warming throughout the country.

Our findings can be particularly important for agriculture, as well as for regional ecological systems such as forests and wetlands, which additionally cover a considerable area in the analyzed territory. Regarding agriculture, our results can contribute to a better management of agricultural crops amid climate changes such as earlier sowing and the introduction of new plant genotypes with high ecological plasticity and improved adaptability to climate warming. This adaptation will be essential over the coming decades, when more severe climate changes are expected to occur in Romania and worldwide.

Author Contributions: Conceptualization, G.B.; methodology, G.B., A.P., C.P. and B.R.: software, A.P., C.P., B.R. and E.D.; validation, G.B., A.P., C.P. and B.R.: formal analysis G.B., investigation, G.B. and E.D.; resources, G.B.; data curation C.P., A.P and B.R.; writing-original draft preparation, G.B.; writing-review and editing, G.B. and B.R.; supervision, G.B.; funding acquisition, B.R. and A.P. All authors have read and agreed to the published version of the manuscript.

Funding: Bogdan Rosca has benefitted from the support of the PN-III-P2-2.1-PED-2019-5436 project, funded by the UEFISCDI program, Romania. Moreover, Adrian Piticar has benefitted from the support of the PN-III-COFUND-SUSCROP-SUSCAP-1 (SUSCAP, contract 106/2019) project, funded by the UEFISCDI program, Romania.

Institutional Review Board Statement: Not applicable.

Informed Consent Statement: Not applicable.

Data Availability Statement: Not applicable. 
Acknowledgments: The authors would like to thank the anonymous reviewers for their highly constructive comments and suggestions that helped improve this paper.

Conflicts of Interest: The authors declare no conflict of interest.

\section{References}

1. Caparros-Santiago, J.A.; Rodriguez-Galiano, V.; Dash, J. Land surface phenology as indicator of global terrestrial ecosystem dynamics: A systematic review. ISPRS J. Photogramm. Remote Sens. 2021, 171, 330-347. [CrossRef]

2. Buitenwerf, R.; Rose, L.; Higgins, S.I. Three decades of multi-dimensional change in global leaf phenology. Nat. Clim. Chang. 2015, 5, 364-368. [CrossRef]

3. Fitchett, J.M.; Grab, S.W.; Thompson, D.I. Plant phenology and climate change: Progress in methodological approaches and application. Prog. Phys. Geog. 2015, 39, 460-482. [CrossRef]

4. Sherry, R.A.; Zhou, X.; Gu, S.; Arnone, J.A., III; Schimel, D.S.; Verburg, P.S.; Wallace, L.L.; Luo, Y. Divergence of reproductive phenology under climate warming. Proc. Natl. Acad. Sci. USA 2007, 104, 198-202. [CrossRef]

5. Piao, S.; Liu, Q.; Chen, A.; Janssens, I.A.; Fu, Y.; Dai, J.; Liu, L.; Lian, X.; Shen, M.; Zhu, X. Plant phenology and global climate change: Current progresses and challenges. Glob. Chang. Biol. 2019, 25, 1922-1940. [CrossRef]

6. Gao, M.; Wang, X.; Meng, F.; Liu, Q.; Li, X.; Zhang, Y.; Piao, S. Three-dimensional change in temperature sensitivity of northern vegetation phenology. Glob. Chang. Biol. 2020, 26, 5189-5201. [CrossRef]

7. Huang, Y.; Jiang, N.; Shen, M.; Guo, L. Effect of preseason diurnal temperature range on the start of vegetation growing season in the Northern Hemisphere. Ecol. Indic. 2020, 112, 106161. [CrossRef]

8. Shen, Y.; Liu, X. Phenological Changes of Corn and Soybeans over U.S. by Bayesian Change-Point Model. Sustainability 2015, 7, 6781-6803. [CrossRef]

9. Li, Q.; Xu, L.; Pan, X.; Zhang, L.; Li, C.; Yang, N.; Qi, J. Modeling phenological responses of Inner Mongolia grassland species to regional climate change. Environ. Res. Lett. 2016, 11, 015002. [CrossRef]

10. Li, X.; Jiang, L.; Meng, F.; Wang, S.; Niu, H.; Iler, A.M.; Duan, J.; Zhang, Z.; Luo, C.; Cui, S.; et al. Responses of sequential and hierarchical phenological events to warming and cooling in alpine meadows. Nat. Commun. 2016, 7, 12489. [CrossRef] [PubMed]

11. Ramos, M.C. Projection of phenology response to climate change in rainfed vineyards in north-east Spain. Agric. For. Meteorol. 2017, 247, 104-115. [CrossRef]

12. Zhu, W.; Jiang, N.; Chen, G.; Zhang, D.; Zheng, Z.; Fan, D. Divergent shifts and responses of plant autumn phenology to climate change on the Qinghai-Tibetan Plateau. Agric. For. Meteorol. 2017, 239, 166-175. [CrossRef]

13. Prăvălie, R. Major perturbations in the Earth's forest ecosystems. Possible implications for global warming. Earth Sci. Rev. 2018, 185, 544-571. [CrossRef]

14. Jeong, S.J.; Ho, C.H.; Gim, H.J.; Brown, M.E. Phenology shifts at start vs. end of growing season in temperate vegetation over the Northern Hemisphere for the period 1982-2008. Glob. Chang. Biol. 2011, 17, 2385-2399. [CrossRef]

15. Peñuelas, J.; Filella, I.; Zhang, X.; Llorens, L.; Ogaya, R.; Lloret, F.; Comas, P.; Estiarte, M.; Terradas, J. Complex spatiotemporal phenological shifts as a response to rainfall changes. New Phytol. 2004, 161, 837-846. [CrossRef] [PubMed]

16. Linderholm, H.W. Growing season changes in the last century. Agric. For. Meteorol. 2006, 137, 1-14. [CrossRef]

17. Nord, E.A.; Lynch, J.P. Plant phenology: A critical controller of soil resource acquisition. J. Exp. Bot. 2009, 60, 1927-1937. [CrossRef]

18. Xie, Y.; Wang, X.; Silander, J.A., Jr. Deciduous forest responses to temperature, precipitation, and drought imply complex climate change impacts. Proc. Natl. Acad. Sci. USA 2015, 112, 13585-13590. [CrossRef] [PubMed]

19. Ruosteenoja, K.; Räisänen, J.; Pirinen, P. Projected changes in thermal seasons and the growing season in Finland. Int. J. Climatol. 2011, 31, 1473-1487. [CrossRef]

20. Way, D.A. Tree phenology responses to warming: Spring forward, fall back? Tree. Physiol. 2011, 31, 469-471. [CrossRef] [PubMed]

21. Ruosteenoja, K.; Räisänen, J.; Venäläinen, A.; Kämäräinen, M. Projections for the duration and degree days of the thermal growing season in Europe derived from CMIP5 model output. Int. J. Climatol. 2015, 36, 3039-3055. [CrossRef]

22. Bethere, L.; Sīle, T.; Sennikovs, J.; Bethers, U. Impact of climate change on the timing of strawberry phonological processes in the Baltic States. Est. J. Earth. Sci. 2016, 65, 48-58. [CrossRef]

23. Cui, L.; Shi, J.; Ma, Y.; Du, H. Distribution and trend in the thermal growing season in China during 1961-2015. Phys. Geogr. 2017, 38, 506-523. [CrossRef]

24. Wypych, A.; Sulikowska, A.; Ustrnul, Z.; Czekierda, D. Variability of growing degree days in Poland in response to ongoing climate changes in Europe. Int. J. Biometeorol. 2017, 61, 49-59. [CrossRef] [PubMed]

25. Bandoc, G.; Prăvălie, R.; Patriche, C.; Dragomir, E.; Tomescu, M. Response of phenological events to climate warming in the southern and south-eastern regions of Romania. Stoch. Environ. Res. Risk Assess. 2018, 32, 1113-1129. [CrossRef]

26. van Vliet, A.J.H.; Bron, W.A.; Mulder van der Slikke, W. Observed climate-induced changes in plant phenology in the Netherlands. Reg. Environ. Change 2014, 14, 997-1008. [CrossRef]

27. Park, T.; Ganguly, S.; Tømmervik, H.; Euskirchen, E.S.; Høgda, K.-A.; Karlsen, S.R.; Brovkin, V.; Nemani, R.R.; Myneni, R. Changes in growing season duration and productivity of northern vegetation inferred from long-term remote sensing data. Environ. Res. Lett. 2016, 11, 084001. [CrossRef] 
28. Karami, M.; Hansen, B.U.; Westergaard-Nielsen, A.; Abermann, J.; Lund, M.; Schmidt, N.M.; Elberling, B. Vegetation phenology gradients along the west and east coasts of Greenland from 2001 to 2015. Ambio 2017, 46, 94-105. [CrossRef]

29. Liu, Y.; Chen, Q.; Ge, Q.; Dai, J.; Qin, Y.; Dai, L.; Zou, X.; Chen, J. Modelling the impacts of climate change and crop management on phenological trends of spring and winter wheat in China. Agric. For. Meteorol. 2018, 248, 518-526. [CrossRef]

30. Zhang, Q.; Kong, D.; Shi, P.; Singh, V.P.; Sun, P. Vegetation phenology on the Qinghai-Tibetan Plateau and its response to climate change (1982-2013). Agric. For. Meteorol. 2018, 248, 408-417. [CrossRef]

31. Dannenberg, M.; Wang, X.; Yan, D.; Smith, W. Phenological characteristics of global ecosystems based on optical, fluorescence, and microwave remote sensing. Remote Sens. 2020, 12, 671. [CrossRef]

32. Yang, X.; Hao, Y.; Cao, W.; Yu, X.; Hua, L.; Liu, X.; Yu, T.; Chen, C. How does spring phenology respond to climate change in ecologically fragile grassland? A case study from the Northeast Qinghai-Tibet Plateau. Sustainability 2021, 13, 12781. [CrossRef]

33. Gordo, O.; Sanz, J.J. Long-term temporal changes of plant phenology in the Western Mediterranean. Glob. Chang. Biol. 2009, 15, 1930-1948. [CrossRef]

34. Fu, Y.S.H.; Campioli, M.; Vitasse, Y.; De Boeck, H.J.; Van den Berge, J.; AbdElgawad, H.; Asard, H.; Piao, S.; Deckmyn, G.; Janssens, I. Variation in leaf flushing date influences autumnal senescence and next year's flushing date in two temperate tree species. Proc. Natl. Acad. Sci. USA 2014, 111, 7355-7360. [CrossRef]

35. Kolářová, E.; Nekovář, J.; Adamík, P. Long-term temporal changes in central European tree phenology (1946-2010) confirm the recent extension of growing seasons. Int. J. Biometeorol. 2014, 58, 1739-1748. [CrossRef] [PubMed]

36. Menzel, A.; Yuan, Y.; Matiu, M.; Sparks, T.; Scheifinger, H.; Gehrig, R.; Estrella, N. Climate change fingerprints in recent European plant phenology. Glob. Change Biol. 2020, 26, 2599-2612. [CrossRef]

37. Jiang, Y.; Li, B.; Yuan, Y.; Sun, Q.; Zhang, T.; Liu, Y.; Li, Y.; Li, R.; Li, F. Trends in flowering phenology of herbaceous plants and its response to precipitation and snow cover on the Qinghai-Tibetan Plateau from 1983 to 2017. Sustainability 2021, 13, 7640. [CrossRef]

38. Ivits, E.; Cherlet, M.; Tóth, G.; Sommer, S.; Mehl, W.; Vogt, J.; Micale, F. Combining satellite derived phenology with climate data for climate change impact assessment. Glob. Planet. Chang. 2012, 88, 85-97. [CrossRef]

39. Piao, S.; Wang, X.; Park, T.; Chen, C.; Lian, X.; He, Y.; Bjerke, J.W.; Chen, A.; Ciais, P.; Tømmervik, H.; et al. Characteristics, drivers and feedbacks of global greening. Nat. Rev. Earth Environ. 2020, 1, 14-27. [CrossRef]

40. Peñuelas, J.; Rutishauser, T.; Filella, I. Phenology feedbacks on climate change. Science 2009, 324, 887-888. [CrossRef]

41. Menzel, A.; Sparks, T.H.; Estrella, N.; Koch, E.; Aasa, A.; Ahas, R.; Alm-Kübler, K.; Bissolli, P.; Braslavská, O.; Briede, A.; et al. European phenological response to climate change matches the warming pattern. Glob. Chang. Biol. 2006, 12, 1969-1976. [CrossRef]

42. Menzel, A.; Fabian, P. Growing season extended in Europe. Nature 1999, 397, 659. [CrossRef]

43. Stockli, R.; Vidale, P.L. European plant phenology and climate as seen in a 20-year AVHRR land-surface parameter dataset. Int. J. Remote Sens. 2004, 25, 3303-3330. [CrossRef]

44. Schröder, W.; Schmidt, G. Schönrock, SModelling and mapping of plant phonological stages as bio-meteorological indicators for climate change. Environ. Sci. Eur. 2014, 26, 5. [CrossRef]

45. Ogawa-Onishi, Y.; Berry, P.M. Ecological impacts of climate change in Japan: The importance of integrating local and international publications. Biol. Conserv. 2013, 157, 361-371. [CrossRef]

46. Buermann, W.; Forkel, M.; O'Sullivan, M.; Sitch, S.; Friedlingstein, P.; Haverd, V.; Jain, A.K.; Kato, E.; Kautz, M.; Lienert, S.; et al. Widespread seasonal compensation effects of spring warming on northern plant productivity. Nature 2018, 562, 110-114. [CrossRef] [PubMed]

47. Wang, X.; Xiao, J.; Li, X.; Cheng, G.; Ma, M.; Zhu, G.; Arain, M.A.; Black, T.A.; Jassal, R.S. No trends in spring and autumn phenology during the global warming hiatus. Nat. Commun. 2019, 10, 2389. [CrossRef] [PubMed]

48. Xu, X.; Riley, W.J.; Koven, C.D.; Jia, G.; Zhang, X. Earlier leaf-out warms air in the north. Nat. Clim. Change 2020, 10, 370-375. [CrossRef]

49. Richardson, A.D.; Keenan, T.F.; Migliavacca, M.; Ryu, Y.; Sonnentag, O.; Toomey, M. Climate change, phenology, and phenological control of vegetation feedbacks to the climate system. Agric. For. Meteorol. 2013, 169, 156-173. [CrossRef]

50. Carter, T.R. Changes in the thermal growing season in Nordic countries during the past century and prospects for the future. Agric. Food Sci. Finl. 1998, 7, 161-179. [CrossRef]

51. Cosmulescu, S.; Baciu, A.; Cichi, M.; Gruia, M. The effect of climate changes on phenological phases in plum tree (Prunusdomestica L.) in south-western Romania. South West. J. Hortic. Biol. Environ. 2010, 1, 9-20.

52. Cosmulescu, S.; Baciu, A.; Gruia, M. Influence of climatic factors on the phenology spring in Southern Oltenia (Romania). J. Hortic. For. Biotechnol. 2015, 19, 147-157.

53. Croitoru, A.-E.; Holobaca, I.-H.; Lazar, C.; Moldovan, F.; Imbroane, A. Air temperature trend and the impact on winter wheat phenology in Romania. Clim. Chang. 2012, 111, 393-410. [CrossRef]

54. Cosmulescu, S.; Ionescu, M.B. Phenological calendar in some walnut genotypes grown in Romania and its correlations with air temperature. Int. J. Biometeorol. 2018, 62, 2007-2013. [CrossRef] [PubMed]

55. Irimia, L.M.; Patriche, C.V.; Quenol, H.; Sfîcă, L.; Foss, C. Shifts in climate suitability for wine production as a result of climate change in a temperate climate wine region of Romania. Theor. Appl. Climatol. 2018, 131, 1069-1081. [CrossRef] 
56. Chitu, E.; Paltineanu, C. Timing of phenological stages for apple and pear trees under climate change in a temperate-continental climate. Int. J. Biometeorol. 2020, 64, 1263-1271. [CrossRef]

57. Marin, L.; Birsan, M.-V.; Bojariu, R.; Dumitrescu, A.; Micu, D.M.; Manea, A. An overview of annual climatic changes in Romania: Trends in air temperature, precipitation, sunshine hours, cloud cover, relative humidity and wind speed during the1961-2013 period. Carpath. J. Earth. Env. 2014, 9, 253-258.

58. Spinoni, J.; Szalai, S.; Szentimrey, T.; Lakatos, M.; Bihari, Z.; Nagy, A.; Németh, Á.; Kovács, T.; Mihic, D.; Dacic, M.; et al. Climate of the Carpathian Region in the period 1961-2010: Climatologies and trends of 10 variables. Int. J. Climatol. 2015, 35, $1322-1341$. [CrossRef]

59. Dumitrescu, A.; Bojariu, R.; Bîrsan, M.V.; Marin, L.; Manea, A. Recent climatic changes in Romania from observational data (1961-2013). Theor. Appl. Climatol. 2015, 122, 111-119. [CrossRef]

60. Sfîcă, L.; Croitoru, A.-E.; Iordache, I.; Ciupertea, A.F. Synoptic conditions generating heat waves and warm spells in Romania. Atmosphere 2017, 8, 50. [CrossRef]

61. Prăvălie, R.; Piticar, A.; Roșca, B.; Sfîcă, L.; Bandoc, G.; Tiscovschi, A.; Patriche, C. Spatio-temporal changes of the climatic water balance in Romania as a response to precipitation and reference evapotranspiration trends during 1961-2013. Catena 2019, 172, 295-312. [CrossRef]

62. Prăvălie, R.; Sîrodoev, I.; Patriche, C.; Roșca, B.; Piticar, A.; Bandoc, G.; Sfîcă, L.; Tişcovschi, A.; Dumitrascu, M.; Chifiriuc, C.; et al The impact of climate change on agricultural productivity in Romania. A country-scale assessment based on the relationship between climatic water balance and maize yields in recent decades. Agric. Syst. 2020, 179, 102767. [CrossRef]

63. Prăvălie, R.; Patriche, C.; Tişcovschi, A.; Dumitraşcu, M.; Săvulescu, I.; Sîrodoev, I.; Bandoc, G. Recent spatio-temporal changes of land sensitivity to degradation in Romania due to climate change and human activities: An approach based on multiple environmental quality indicators. Ecol. Indic. 2020, 118, 106755. [CrossRef]

64. Bandoc, G.; Mateescu, R.; Dragomir, E.; Golumbeanu, M.; Comanescu, L.; Nedelea, A. Systemic approach of the impact induced by climate changes on hydrothermic factors at the Romanian Black Sea coast. J. Environ. Protect. Ecol. 2014, 15, 455-467.

65. Bandoc, G.; Prăvălie, R. Climatic water balance dynamics over the last five decades in Romania's most arid region, Dobrogea. J. Geogr. Sci. 2015, 25, 1307-1327. [CrossRef]

66. Prăvălie, R.; Sîrodoev, I.; Patriche, C.V.; Bandoc, G.; Peptenatu, D. The analysis of the relationship between climatic water deficit and corn agricultural productivity in the Dobrogea plateau. Carpathian J. Earth Environ. Sci. 2014, 9, 201-214.

67. Prăvălie, R.; Patriche, C.V.; Sîrodoev, I.; Bandoc, G.; Dumitraşcu, M.; Peptenatu, D. Water deficit and corn productivity during the post-socialist period. Case study: Southern Oltenia drylands, Romania. Arid. Land Res. Manag. 2016, 30, 239-257. [CrossRef]

68. Prăvălie, R.; Bandoc, G.; Patriche, C.; Tomescu, M. Spatio-temporal trends of mean air temperature during 1961-2009 and impacts on crop (maize) yields in the most important agricultural region of Romania. Stoch. Environ. Res. Risk Assess. 2017, 31, 1923-1939. [CrossRef]

69. Prăvălie, R.; Bandoc, G. Aridity variability in the last five decades in the Dobrogea region, Romania. Arid. Land Res. Manag. 2015, 29, 265-287. [CrossRef]

70. Irimia, L.M.; Patriche, C.V.; Roșca, B. Climate change impact on climate suitability for wine production in Romania. Theor. Appl. Climatol. 2017, 133, 1-14. [CrossRef]

71. Ichim, P.; Sfîcă, L. The influence of urban climate on bioclimatic conditions in the city of Iași, Romania. Sustainability 2020, 12, 9652. [CrossRef]

72. Sandu, I.; Pescaru, V.I.; Poiana, I.; Geicu, A.; Candea, I.; Tastea, D. The Climate of Romania; Romanian Academy Publishing: Bucharest, Romania, 2008. (In Romanian)

73. EEA. European Environment Agency-CORINE Land Cover 2018, Copernicus Programme, Copernicus Land Monitoring Service. 2018. Available online: https:/ /land.copernicus.eu/pan-european/corine-land-cover/clc2018 (accessed on 13 January 2022).

74. Vâtca, S.D.; Stoian, V.A.; Man, T.C.; Horvath, C.; Vidican, R.; Gâdea, S.; Vâtca, A.; Rotaru, A.; Vârban, R.; Cristina, M.; et al. Agrometeorological requirements of maize crop phenology for sustainable cropping-A historical review for Romania. Sustainability 2021, 13, 7719. [CrossRef]

75. NMA. National Meteorological Administration-Data Series Regarding Mean Monthly Air Temperature Values Recorded at the Calafat, Bechet, Pitesti, Videle, Giurgiu, Ploiesti, Adjud, Grivita, Braila, Medgidia, Corugea, Mangalia and Sfantu Gheorghe Weather Stations; NMA: Bucharest, Romania, 2015.

76. Klein Tank, A.M.G.; Wijngaard, J.B.; Können, G.P.; Bohm, R.; Demaree, G.; Gocheva, A.; Mileta, M.; Pashiardis, S.; Hejkrlik, L.; Kern-Hansen, C.; et al. Daily dataset of 20th-century surface air temperature and precipitation series for the European climate assessment. Int. J. Climatol. 2002, 22, 1441-1453. [CrossRef]

77. Dumitrescu, A.; Birsan, M.V. ROCADA: A gridded daily climatic dataset over Romania (1961-2013) for nine meteorological variables. Nat. Hazards 2015, 78, 1045-1063. [CrossRef]

78. Bandoc, G. Costal phenologic cycles for Sfantu Gheorghe station (the Danube Delta). J. Environ. Protect. Ecol. 2008, 9, 953-960.

79. Manea, G. Biogeography Elements; University of Bucharest Publishing House: Bucharest, Romania, 2008. (In Romanian)

80. Vitasse, Y.; Delzon, S.; Dufrêne, E.; Pontailler, J.Y.; Louvet, J.M.; Kremer, A.; Michalet, R. Leaf phenology sensitivity to temperature in European trees: Do within-species populations exhibit similar responses? Agric. For. Meteorol. 2009, 149, 735-744. [CrossRef]

81. Frich, P.; Alexander, L.V.; Della-Marta, P.; Gleason, B.; Haylock, M.; Klein Tank, A.M.G.; Peterson, T. Observed coherent changes in climatic extremes during the second half of the twentieth century. Clim. Res. 2002, 19, 193-212. [CrossRef] 
82. Walther, A.; Linderholm, H.W. A comparison of growing season indices for the Greater Baltic Area. Int. J. Biometeorol. 2006, 51, 107-118. [CrossRef]

83. Liu, B.; Henderson, M.; Zhang, Y.; Xu, M. Spatiotemporal change in China's climatic growing season: 1955-2000. Clim. Change 2010, 99, 93-118. [CrossRef]

84. Zheng, H.; McLaughlin, N.B.; He, X.; Yu, X.; Ren, Z.; Zhang, D. Temporal and geographical variation in the onset of climatological spring in Northeast China. Theor. Appl. Climatol. 2013, 114, 605-613. [CrossRef]

85. Mueller, B.; Hauser, M.; Iles, C.; Rimi, R.H.; Zwiers, F.W.; Wan, H. Lengthening of the growing season in wheat and maize producing regions. Weather. Clim. Extrem. 2015, 9, 47-56. [CrossRef]

86. Potopová, V.; Zahradníček, P.; Türkott, L.; Štěpánek, P.; Soukup, J. The effects of climate change on variability of the growing seasons in the Elbe river lowland, Czech Republic. Adv. Meteorol. 2015, 2015, 546920. [CrossRef]

87. Aalto, J.; Pirinen, P.; Kauppi, P.E.; Rantanen, M.; Lussana, C.; Lyytikäinen-Saarenmaa, P.; Gregow, H. High-resolution analysis of observed thermal growing season variability over northern Europe. Clim. Dyn. 2021, 57, 2171-2188. [CrossRef]

88. Cui, L.; Shi, J. Evaluation and comparison of growing season metrics in arid and semi-arid areas of northern China under climate change. Ecol. Indic. 2021, 121, 107055. [CrossRef]

89. Cenușă, R. Research on Forest Vegetation Dynamics (Phenology); Institute of Forest and Wildlife Research and Development: Bucharest, Romania, 2003. (In Romanian)

90. MATLAB. MATLAB and Statistics Toolbox Release; MathWorks: Natick, MA, USA, 2012.

91. Mann, H.B. Nonparametric tests against trend. Econometrica 1945, 13, 245-259. [CrossRef]

92. Kendall, M.G. Rank Correlation Methods; Griffin: London, UK, 1975.

93. Sen, P.K. Estimates of the regression coefficient based on Kendall's tau. J. Am. Stat. Assoc. 1968, 63, 1379-1389. [CrossRef]

94. Salmi, T.; Määttä, A.; Anttila, P.; Ruoho-Airola, T.; Amnell, T. Detecting Trends of Annual Values of Atmsopheric Pollutants by the Mann-Kendall Test and Sen's Slope Estimates_the Excel Template Application Makesens; Finnish Meteorological Institute: Helsinki, Finland, 2002.

95. Gilbert, R.O. Statistical Methods for Environmental Pollution Monitoring; Van Nostrand Reinhold: New York, NY, USA, 1987.

96. Mohsin, T.; Gough, W.A. Trend analysis of long-term temperature time series in the Greater Toronto Area (GTA). Theor. Appl. Climatol. 2010, 101, 311-327. [CrossRef]

97. Appiotti, F.; Krželj, M.; Russo, A.; Ferretti, M.; Bastianini, M.; Marincioni, F. A multidisciplinary study on the effects of climate change in the northern Adriatic Sea and the Marche region (central Italy). Reg. Environ. Change 2014, 14, 2007-2024. [CrossRef]

98. Cheval, S.; Birsan, M.V.; Dumitrescu, A. Climate variability in the Carpathian Mountains Region over 1961-2010. Glob. Planet. Change 2014, 118, 85-96. [CrossRef]

99. Mamara, A.; Argiriou, A.A.; Anadranistakis, M. Recent trend analysis of mean air temperature in Greece based on homogenized data. Theor. Appl. Climatol. 2016, 126, 543-573. [CrossRef]

100. Croitoru, A.E.; Chiotoroiu, B.C.; Todorova, V.I.; Torica, V. Changes in precipitation extremes on the Black Sea Western Coast. Glob. Planet. Change 2013, 102, 10-19. [CrossRef]

101. ESRI. ArcGIS Desktop: Release 10.1, Redlands, CA; Environmental Systems Research Institute: Redlands, CA, USA, 2012.

102. Kalvāne, G.; Romanovskaja, D.; Briede, A.; Bakšienè, E. Influence of climate change on phenological phases in Latvia and Lithuania. Clim. Res. 2009, 39, 209-219. [CrossRef]

103. Dai, J.; Wang, H.; Ge, Q. Characteristics of spring phenological changes in China over the past 50 years. Adv. Meteorol. 2014, 2014, 843568. [CrossRef]

104. Keenan, T.F.; Gray, J.; Friedl, M.A.; Toomey, M.; Bohrer, G.; Hollinger, D.Y.; Munger, J.W.; O'Keefe, J.; Schmid, H.P.; Wing, I.S.; et al. Net carbon uptake has increased through warming-induced changes in temperate forest phenology. Nat. Clim. Change 2014, 4 598-604. [CrossRef]

105. Wang, C.; Guo, H.; Zhang, L.; Liu, S.; Qiu, Y.; Sun, Z. Assessing phenological change and climatic control of alpine grasslands in the Tibetan Plateau with MODIS time series. Int. J. Biometeorol. 2015, 59, 11-23. [CrossRef]

106. Suepa, T.; Qi, J.; Lawawirojwong, S.; Messina, J.P. Understanding spatio-temporal variation of vegetation phenology and rainfall seasonality in the monsoon Southeast Asia. Environ. Res. 2016, 147, 621-629. [CrossRef] [PubMed]

107. Bucha, T.; Koren, M. Phenology of the beech forests in the Western Carpathians from MODIS for 2000-2015. Iforest 2017, 10, 537-546. [CrossRef]

108. Huang, J.; Li, J. Spring phenology of cotton bollworm affects wheat yield. Ecol. Evol. 2016, 7, 1078-1090. [CrossRef] [PubMed]

109. Kiapasha, K.; Darvishsefat, A.A.; Julien, Y.; Sobrino, J.A.; Zargham, N.; Attord, P.; Schaepman, M.E. Trends in phenological parameters and relationship between land surface phenology and climate data in the Hyrcanian Forests of Iran. IEEE J. Sel. Top. Appl. 2017, 10, 4961-4970. [CrossRef]

110. Hiemstra, P.H.; Pebesma, E.J.; Twenhöfel, C.J.W.; Heuvelink, G.B.M. Real-time automatic interpolation of ambient gamma dose rates from the Dutch radioactivity monitoring network. Comput. Geosci. 2009, 35, 1711-1721. [CrossRef]

111. XLSTAT. Data Analysis and Statistical Solution for Microsoft Excel; Addinsoft: Paris, France, 2017.

112. Barichivich, J.; Briffa, K.R.; Osborn, T.J.; Melvin, T.M.; Caesar, J. Thermal growing season and timing of biospheric carbon uptake across the Northern Hemisphere. Global Biogeochem. Cycles 2012, 26, GB4015. [CrossRef]

113. Zeng, H.; Jia, G.; Epstein, H. Recent changes in phenology over the northern high latitudes detected from multi-satellite data. Environ. Res. Lett. 2011, 6, 045508. [CrossRef] 
114. Chmielewski, F.M.; Rötzer, T. Response of tree phenology to climate change across Europe. Agric. For. Meteorol. 2001, 108, 101-112. [CrossRef]

115. Fatima, Z.; Ahmed, M.; Hussain, M.; Abbas, G.; Ul-Allah, S.; Ahmad, S.; Ahmed, N.; Ali, M.A.; Sarwar, G.; Haque, E.U.; et al. The fingerprints of climate warming on cereal crops phenology and adaptation options. Sci. Rep. 2020, 10, 18013. [CrossRef] [PubMed]

116. Meng, L.; Zhou, Y.; Li, X.; Asrar, G.R.; Mao, J.; Wanamaker, A.D.; Wang, Y. Divergent responses of spring phenology to daytime and nighttime warming. Agric. For. Meteorol. 2020, 281, 107832. [CrossRef]

117. Körner, C.; Basler, D. Phenology under global warming. Science 2010, 327, 1461-1462. [CrossRef]

118. Szabó, B.; Vincze, E.; Czúcz, B. Flowering phenological changes in relation to climate change in Hungary. Int. J. Biometeorol. 2016, 60, 1347-1356. [CrossRef]

119. Rezaei, E.E.; Siebert, S.; Ewert, F. Climate and management interaction cause diverse crop phenology trends. Agric. For. Meteorol. 2017, 233, 55-70. [CrossRef]

120. Bertin, R.I. Plant phenology and distribution in relation to recent climate change. J. Torrey Bot. Soc. 2008, 135, 126-146. [CrossRef] 